\title{
Grystallization History of Lunar Feldspathic Basalt 14310
}

\section{GEOLOGICAL SURVEY PROFESSIONAL PAPER 841}

Prepared on behalf of the

National Aeronautics and Space Administration

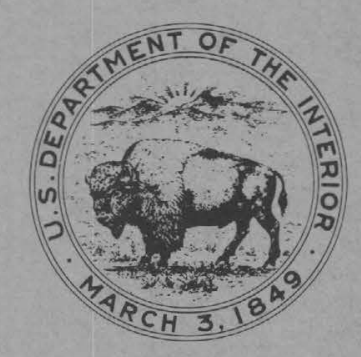





\section{Crystallization History of Lunar Feldspathic Basalt 14310}

By ODETTE B. JAMES

GEOLOGICAL S URVEY PROFESIONAL PAPER 841

Prepared on behalf of the

National Aeronautics and Space Administration

An account of the crystallization history

of an unusual type of lunar basalt, deduced from detailed petrographic

studies and microprobe mineral analyses

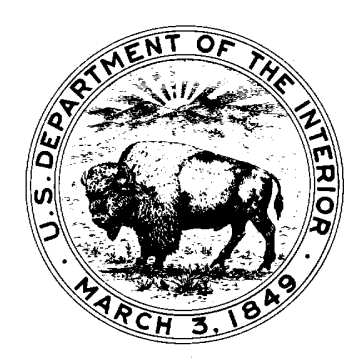

\begin{tabular}{llllll}
\hline UNITED & STATES & GOVERNMENT & PRINTING & OFFICE, & WASHINGTON $: 1973$
\end{tabular} 


\section{UNITED STATES DEPARTMENT OF THE INTERIOR}

ROGERS C. B. MORTON, Secretary

\section{GEOLOGICAL SURVEY}

V. E. McKelvey, Director

Library of Congress catalog-card No. 73-600177

For sale by the Superintendent of Documents U.S. Government Printing Office Washington, D.C. 20402 - Price 70 cents domestic postpaid or 50 cents GPO Bookstore Stock Number 2401-00361 


\section{CONTENTS}

Abstract

Introduction

Mineral assemblage and texture

General features

Locally developed fine-scale textures

Orthopyroxene with preserved euhedral faces

Composite grains with orthopyroxene cores and pigeonite rims

Coarse polysynthetically twinned pigeonite

$\mathrm{Ni}-\mathrm{Fe}$, schreibersite, and troilite

Phase compositions

Subhedral laths

Grains enclosing metal-schreibersite-troilite inclusions

Laths adjacent to vugs _._.

Laths in fine-grained clots _...........--

Orthopyroxene with preserved euhedral crystal faces

Orthopyroxene adjacent to vugs _.........

Orthopyroxene containing blebs and $\{100\}$

lamellae of augite

Orthopyroxene formed by inversion of

pigeonite
Orthopyroxene

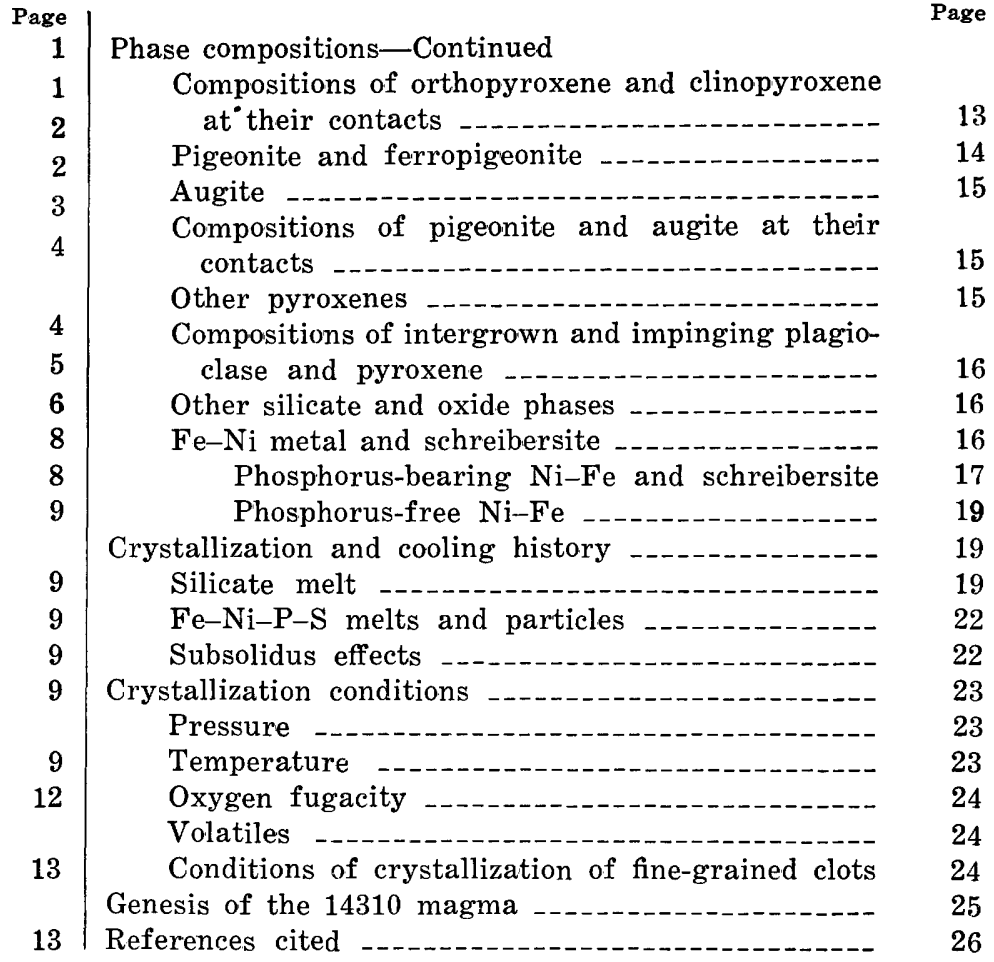

\section{ILLUSTRATIONS}

Figures 1-10. Photomicrographs showing:

1. General features of rock texture

2. Fine-grained clots

3. Composite orthopyroxene-pigeonite-augite grain

4. Orthopyroxene grains -

5. Composite orthopyroxene-pigeonite grains

6. Composite orthopyroxene-pigeonite grain

7. Composite orthopyroxene-pigeonite-augite grain

8. Coarse polysynthetically twinned grain of pigeonite

9. Large composite, globules of $\mathrm{Ni}-\mathrm{Fe}$, schreibersite, and troilite

10. Globule of $\mathrm{Ni}-\mathrm{Fe}+$ schreibersite included in plagioclase

11. Diagrams showing variation in $\mathrm{Ca}, \mathrm{K}$, and $\mathrm{Na}$ along profiles within three large plagioclase laths ..-

12. Plot of Wo:En:Fs contents of pyroxenes analyzed in this study

13. Diagrams showing variations in $\mathrm{Mg}, \mathrm{Ca}$, and $\mathrm{Fe}$ contents across a composite orthopyroxene-pigeoniteaugite grain

14. Plot of Wo:En:Fs contents of points on profiles shown on figure 13

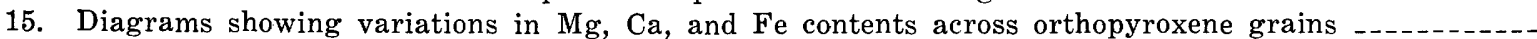

16. Plot of Wo:En:Fs contents of exsolution-free orthopyroxene, orthopyroxene with augite lamellae, and pigeonite at their contacts 
Figure 17. Diagrams showing variations in $\mathrm{Mg}, \mathrm{Ca}$, and Fe contents across orthopyroxene-pigeonite contacts --

17. Diagrams showing variations in $\mathrm{Mg}, \mathrm{Ca}$, and $\mathrm{Fe}$ contents across orthopyroxene-pigeonite contacts --

19. Plot of $\mathrm{Ni}$ and Co contents of grains of phosphorous-bearing and phosphorous-free $\mathrm{Ni-Fe}$

20. Diagrams showing variations in $\mathrm{Ni}$ and Co contents across large $\mathrm{Fe}-\mathrm{Ni}-\mathrm{P}-\mathrm{S}$ globules

21. Plots of $\mathrm{Ni}$ and $\mathrm{Co}$ contents of a Ni-Fe, $\gamma \mathrm{Ni}-\mathrm{Fe}$, and schreibersite in large Fe-Ni-P-S globules .--

22. Plot of $\mathrm{Ni}$ and $\mathrm{Co}$ contents of a $\mathrm{Ni}-\mathrm{Fe}, \gamma \mathrm{Ni}-\mathrm{Fe}$, and schreibersite included in plagioclase 


\title{
CRYSTALLIZATION HISTORY OF LUNAR FELDSPATHIC BASALT 14310
}

\author{
By Odette B. James
}

\begin{abstract}
Lunar feldspathic basalt 14310 crystallized at or near the lunar surface from a melt of virtually the same bulk composition as the rock now has. This melt contained no silieate xenoliths or xenocrysts and probably no phenocrysts, but meteorite-derived $\mathrm{Fe}-\mathrm{Ni}-\mathrm{P}-\mathrm{S}$ melt globules (and possibly also solid particles) were present. Plagioclase was the first silicate to form, at about $1310^{\circ}-1320^{\circ} \mathrm{C}$. After crystallization began there was no abrupt volatilization of alkalis from the melt. Orthopyroxene was the second major silicate to precipitate; some grains of this mineral show complex oscillatory and reverse zoning probably related to local variations in volatile content of the melt. As crystallization progressed in the silicate melt: (1) orthopyroxene reacted with liquid and pigeonite precipitated; (2) augite precipitated; (3) ilmenite precipitated; (4) augite crystallization ceased; and (5) mesostasis minerals crystallized and mesostasis glasses solidified. During crystallization of the silicate melt the globules of Fe-Ni-P-S melt it contained precipitated first $\mathrm{Ni}-\mathrm{Fe}$, then schreibersite, and then troilite. Characteristics of these particles indicate that the 14310 melt was not quenched at any time during its crystallization, that final solidification of the rock took place at about $950^{\circ} \mathrm{C}$, and that subsolidus equilibration continued to below $550^{\circ} \mathrm{C}$. Oxygen fugacity throughout crystallization was about comparable to that in Apollo 12 basaltic melts.

The 14310 melt could have been generated by: (1) partial or bulk melting of a feldspathic rock in the lunar crust; or (2) impact melting of feldspar-rich lunar surface materials. The latter alternative is favored here.
\end{abstract}

\section{INTRODUCTION}

Feldspathic basalt 14310 occupies a position of unique importance to lunar petrology, for this rock crystallized from a melt generated in a different geologic setting, and at an earlier time, than most lunar basalts brought back to earth. Most basalts brought back by the Apollo missions to date were collected from mare surfaces at the Apollo 11, 12, and 15 sites. Basalt fragments form a large percentage of the samples from these sites, and they were presumably derived from flows and sills that form local bedrock. Crystallization ages are in the range $3.15-3.70$ b.y. (billion years). (See references on $\mathrm{Rb} / \mathrm{Sr}$ and
${ }^{40} \mathrm{Ar} /{ }^{39} \mathrm{Ar}$ ages in Proceedings Volumes of the Apollo 11, Second, and Third Lunar Science Conferences, and the volume of Apollo 15 short papers published by the Lunar Science Institute, Houston, Tex.). In contrast, basalt 14310 was collected at the Apollo 14 site on the Fra Mauro formation, a geologic unit interpreted as an ejecta deposit from the impact event that formed the Imbrian basin (Swann and others, 1971). At this site the rocks on the moon's surface are apparently nearly all breccias; only two specimens of basalt weighing more than 50 grams were returned, and 14310 is by far the larger of these. These basalts are probably not derived from local basaltic bedrock, but are instead fragments broken and transported far from their sites of crystallization by processes associated with impact events. Minimum age of crystallization of 14310 is about 3.91 b.y., and minimum age of crystallization of 14053 , the other Apollo 14 basalt hand specimen, is about 3.95 b.y. (results of $\mathrm{Rb} / \mathrm{Sr}$ and ${ }^{40} \mathrm{Ar} /{ }^{39} \mathrm{Ar}$ methods reported by Turner and others, 1971; Papanastassiou and Wasserburg, 1971; Murthy and others, 1972; Compston and others, 1972b; and York and others, 1972).

Basalt 14310 is further of special interest because it appears to have crystallized from a parent melt much different in composition from the parent melts of the mare basalts, and of basalt 14053 as well. Mare basalts as a group, along with 14053, are typified by: dominance of pyroxene over plagioclase; presence of olivine as a common minor, sometimes major, constituent; virtual absence of orthopyroxene and dominance of calcic pyroxene over pigeonite; high content of $\mathrm{FeO}$ (16-23 percent) with attendant high ratio of $\mathrm{FeO} / \mathrm{MgO}$; and very low contents of $\mathrm{K}, \mathrm{P}$, and $\mathrm{Zr}$. In 14310, however, plagioclase is dominant over pyroxene, olivine is absent, orthopyroxene is an important constituent, pigeonite is dominant over augite, content of $\mathrm{FeO}$ is low and about equal to the content of $\mathrm{MgO}$ (Kushiro and others, 1972; Rose and others, 1972; Philpotts and others, 1972; Hubbard and others, 1972; Willis and 
others, 1972; Compston and others, 1972a), and contents of $\mathrm{K}, \mathrm{P}$, and $\mathrm{Zr}$ are $11 / 2-2$ times as high as in the mare basalts that are richest in these elements.

This paper presents an account of the crystallization history of the parent magma of basalt 14310 and its crystallization conditions, deduced from detailed petrographic and electron-microprobe studies of thin sections. Also included is a discussion of possible origins of the melt. The thin sections studied in detail were subsamples 25 and 9 ; supplementary microprobe analyses were made on grains in subsamples 4,14, 30,168, and 179, and 12 other thin sections were examined petrographically.

Acknowledgments.-This work was done under NASA contract T-75412. I thank my colleagues E. C. T. Chao and R. T. Helz for discussion of many points in the paper and review of the manuscript. I am indebted to Judith B. Best for assistance in preparation of the illustrations and final assembly of the manuscript.

\section{MINERAL ASSEMBLAGE AND TEXTURE} GENERAL FEATURES

Major constituents of 14310 are plagioclase and pyroxene (orthopyroxene, pigeonite, augite); important minor constituents are ilmenite, metallic $\mathrm{Ni}-\mathrm{Fe}$, schreibersite, troilite, and mesostasis (a complex intergrowth of late-stage phases). Proportions of these constituents, computed from a bulk-rock analysis (Rose and others, 1972) using the chemicalmode-calculation method described by Wright and Doherty (1970), are as follows (weight percent and volume percent calculated from weight percent, respectively) : plagioclase, 57.3, 62.0; pyroxene, 37.0, 32.2 ; oxides (ilmenite + ulvöspinel), 1.6, 1.0; and mesostasis (silica-rich glass + apatite + potassium feldspar), 4.1, 4.8. Proportions of major minerals indicated by this calculation correspond fairly closely with proportions derived from optical point counts (Melson and others, 1972).

The rock texture ranges from fine-grained subophitic to fine-grained intergranular and is locally intersertal (fig. 1). Plagioclase forms a network of randomly oriented interlocking laths, most of which are subhedral. Feldspar grain-size distribution is roughly seriate rather than bimodal or porphyritic (Drever and others, 1972; Kushiro and others, 1972) ; the laths are as much as $2 \mathrm{~mm}$ long and the average is about $0.2-0.3 \mathrm{~mm}$ long. Many large and intermediate-sized laths $(>0.1 \mathrm{~mm})$ exhibit optically discernible normal progressive zoning and traces of oscillatory zoning that define euhedral crystal outlines throughout their interiors. Pigeonite, the most

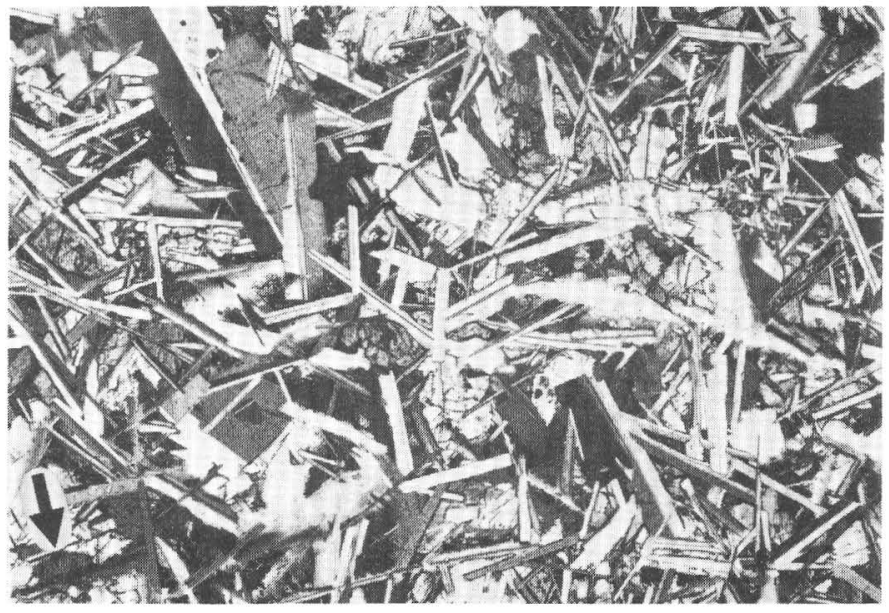

Figure 1.-Photomicrograph of 14310,9 . Seriate plagioclase forms a network of randomly oriented laths; interstices are filled with subophitic and intergranular pyroxene. The large plagioclase lath at upper left contains small $\mathrm{Ni}-\mathrm{Fe}$ inclusions (black). A large particle of $\mathrm{Ni}-\mathrm{Fe}$ (black) and a small clot of fine-grained plagioclase are at upper right. Pigeonite grain at lower left contains an equant core of orthopyroxene (marked by arrow). Width of field of view is $2.2 \mathrm{~mm}$; crossed polarizers.

abundant of the pyroxene minerals, forms intergranular to subophitic grains in the interstices of the plagioclase network. Most orthopyroxene forms cores within the pigeonite grains; where orthopyroxene is directly intergrown with plagioclase with no intervening pigeonite, the intergrowth tends to be graphic rather than subophitic. Most augite forms epitaxial overgrowths on, or zones within, pigeonite grains, but minute amounts of this mineral also occur as small blebs or stubby exsolved prisms within orthopyroxene grains.

Textures of the minor constituents are as follows. $\mathrm{Ni}-\mathrm{Fe}$, schreibersite, and troilite form single phase or composite particles that range from large globules (as much as $0.3 \mathrm{~mm}$ across) to minute irregular interstitial grains. Most particles of these phases are isolated and occur in interstices, but a few are also included in plagioclase and pyroxene. Ilmenite occurs as small subhedra that are restricted to marginal zones of pyroxene grains and interstices. Mesostasis fills interstices and consists of small crystals of ilmenite, ulvöspinel, pyroxene, fayalite, potassium feldspar, baddeleyite, tranquillityite, apatite, and whitlockite and patches of silica-rich and devitrified iron-rich glasses.

The rock shows appreciable textural heterogeneity. Locally, patches of the silicate intergrowth have grain size significantly coarser than in the rest of the rock; many of these patches are associated with open vugs. Patches where the silicate intergrowth is 

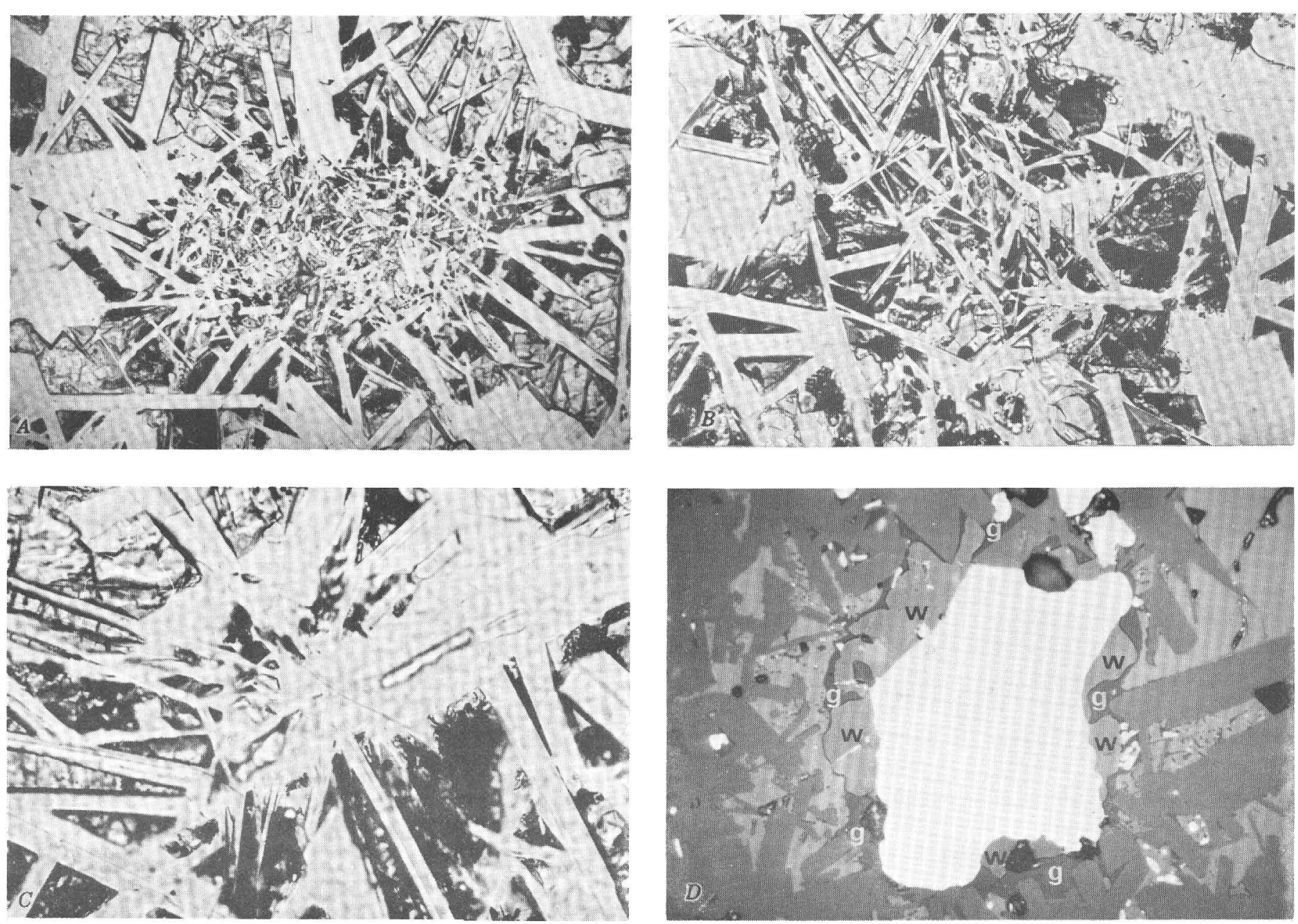

FIGURE 2.-Photomicrographs of fine-grained clots. A, Large clot consisting dominantly of minute plagioclase laths, subordinately of interstitial pyroxene in optical continuity. The basalt immediately surrounding the clot contains a concentration of interstitial mesostasis material (black). Width of field of view is $0.88 \mathrm{~mm}$; plane-polarized light. $B$, Clot consisting of open framework of minute plagioclase laths with abundant interstitial silica-rich glass. Width of field of view is $0.58 \mathrm{~mm}$; plane-polarized light. $C$, Minute plagioclase laths that nucleated on a larger plagioclase grain. Width of field of view is $0.41 \mathrm{~mm}$; plane-polarized light. $D$, Ni-Fe particle within fine-grained clot. The Ni-Fe (white) is enclosed by a reaction rim of whitlockite $(w)$ and silica glass $(g)$. The surrounding clot consists of plagioclase (dark-gray laths) and pyroxene (interstitial light-gray phase). Some of the pyroxene near the whitlockite reaction rim contains minute blebs of silica glass and appears partly resorbed. Width of field of view is $0.31 \mathrm{~mm}$; reflected light.

extremely fine grained are also present locally (fig. 2 ). These range in size from clots $2 \mathrm{~mm}$ across to tiny clots of only a few grains. The larger clots consist dominantly of minute tightly intergrown plagioclase laths; pyroxene is greatly subordinate and forms interstitial grains that are commonly in optical continuity over large areas within single clots. Within most of these larger clots, phases other than plagioclase and pyroxene are absent; however, the network of plagioclase surrounding many of them contains a significantly greater proportion of interstitial mesostasis material than elsewhere in the rock (fig. $2 A$ ). Some of the smaller clots show tex- tures gradational into textures more typical of the rock as a whole: Some are open frameworks of minute plagioclase laths with abundant interstitial glass (fig. $2 B$ ) and others appear to have grown on or around larger plagioclase grains fig. $2 C$ ).

\section{LOCALLY DEVELOPED FINE-SCALE TEXTURES}

Several phases-most notably orthopyroxene, pigeonite, and intergrown $\mathrm{Ni}-\mathrm{Fe}$ and schreibersitelocally show fine-scale textures whose origin has special bearing on interpretation of the crystallization history and origin of the rock. The textures are described below, and compositional variations shown 
by phases with these textures are presented in later sections.

\section{ORTHOPYROXENE WITH PRESERVED EUHEDRAL FACES}

Many orthopyroxene grains contain clouds of minute inclusions of a low-refractive-index phase that appears to be glass. In sparse grains, such inclusions are arranged along planes that mark the traces of euhedral growth surfaces within the crystals, and the orientations of these planes provide evidence as to the structure of the pyroxene that initially crystallized from the melt. Figures $3,4 A$, and $5 \mathrm{~A}$ illustrate three grains in which euhedral faces are preserved. The results of Universal-stage studies show that in such grains the best developed euhedral growth surface are parallel to $\{100\}$; faces parallel to $\{210\}$ planes are less well developed, and faces parallel to $\{010\}$ are rare.

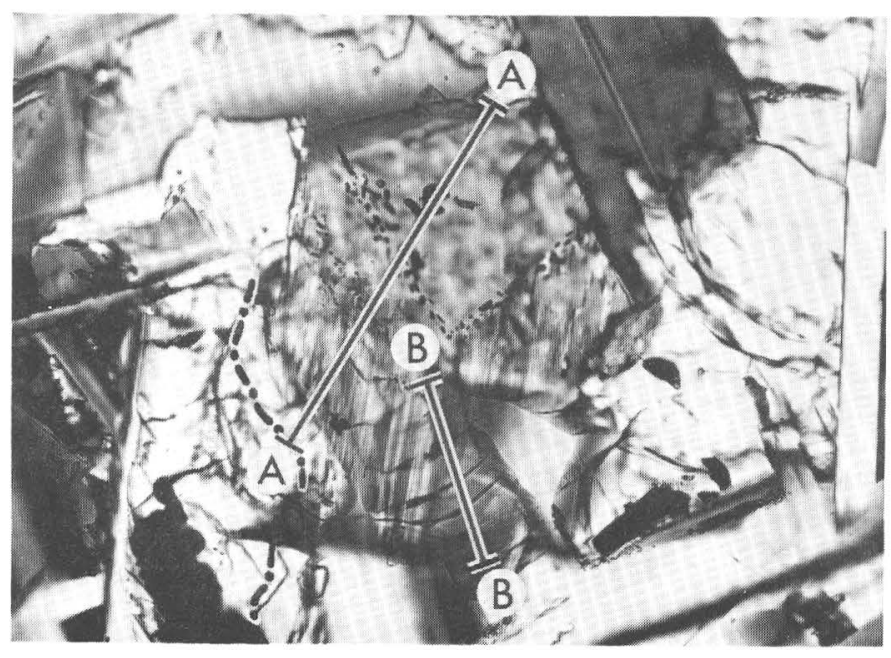

FIGURE 3.-Photomicrograph of composite orthopyroxenepigeonite-augite grain. The orthopyroxene (gray, center) has a core (center top) that is outlined by the traces of $\{210\}$ faces marked by concentrations of glass inclusions. The outer part of the orthopyroxene grain contains abundant exsolution lamellae of augite parallel $\{100\}$ of the host. The dot-dash line marks the contact of pigeonite and augite. Lines marked $A-A$ and $B-B$ indicate traces of microprobe profiles for which compositional data are presented on figures 13 and 14. Width of field of view is $0.31 \mathrm{~mm}$; crossed polarizers.

\section{COMPOSITE GRAINS WITH ORTHOPYROXENE CORES AND PIGEONITE RIMS}

In nearly all the composite grains of these two pyroxenes, textures suggest that the orthopyroxene cores crystallized from melt as orthopyroxene. In a small proportion of the grains, the textures indicate the nature of the crystallization relationship between the orthopyroxene and surrounding pigeonite; the
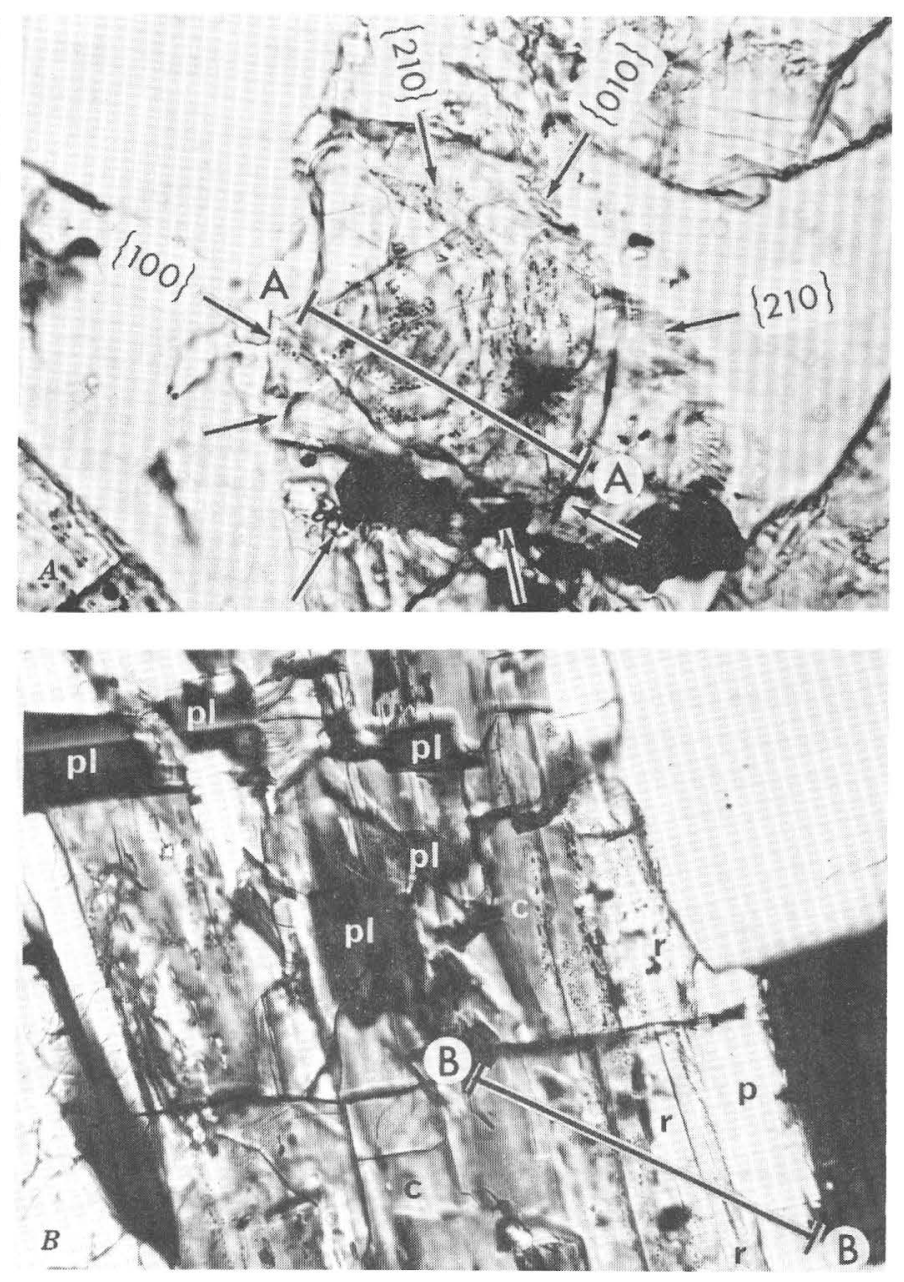

FIGURE 4.-Photomicrographs of orthopyroxene grains. $A$, Grain showing traces of euhedral growth surfaces. Orientations of the crystallographic planes are indicated on the photomicrograph. The line marked $A-A$ indicates the trace of a microprobe profile for which compositional data are plotted on figure 15. Width of field of view is $0.28 \mathrm{~mm}$; plane-polarized light. $B$, Grain bordering a vug. Orthopyroxene at the core (c) of the grain is graphically intergrown with plagioclase $(\mathrm{pl})$. Along its right edge the orthopyroxene core is rimmed by orthopyroxene of slightly different extinction position ( $r)$, which is in turn rimmed by pigeonite (p) adjacent to the vug (black). The line labeled $B-B$ indicates the trace of a microprobe profile plotted on figure 15. Width of field of view is 0.35 $\mathrm{mm}$; crossed polarizers.

variations in these textures demonstrate that there were significant local variations in pyroxene crystallization history. In some grains the orthopyroxene core is clearly euhedral and did not react with surrounding melt before or during overgrowth by pigeonite (fig. $5 \mathrm{~A}$ ). In contrast, in other grains the orthopyroxene core is irregular and may have been partly resorbed (fig. $5 B$ ). In most composite grains, however, the presence or absence of reaction rela- 

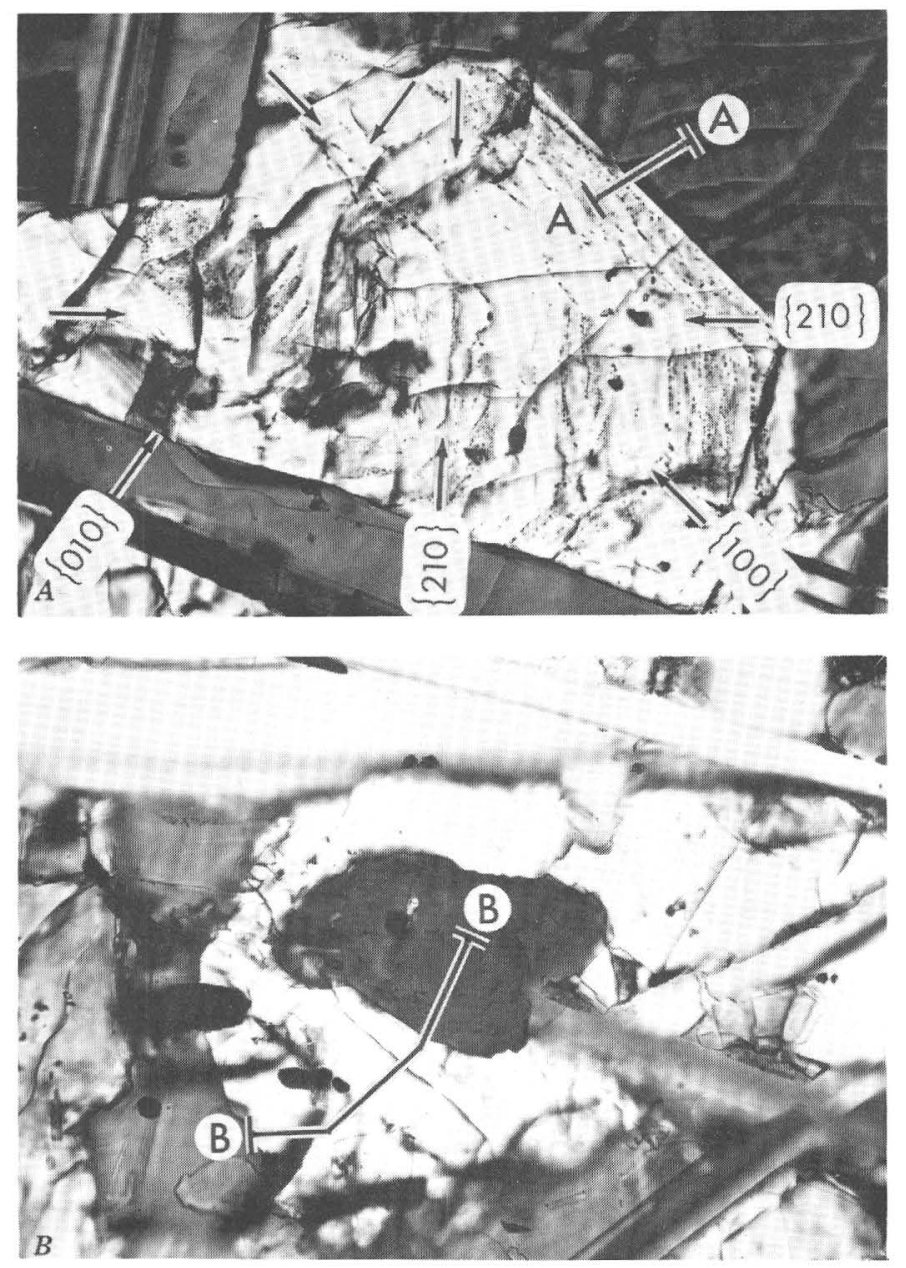

FIGURE 5.-Photomicrographs of composite orthopyroxenepigeonite grains. $A$, Euhedral orthopyroxene core in pigeonite. Traces of euhedral growth surfaces within the orthopyroxene core are marked by planes rich in glass inclusions; crystallographic orientations of these planes are indicated on the photomicrograph. The line designated $A-A$ indicates the position of a microprobe profile across the orthopyroxene-pigeonite contact for which compositional data are presented on figure 17. Width of field of view is $0.35 \mathrm{~mm}$; crossed polarizers. $B$, Irregular orthopyroxene core in pigeonite. The line designated $B-B$ is the trace of a microprobe profile for which compositional data are plotted on figure 17. Width of field of view is $0.35 \mathrm{~mm}$; crossed polarizers.

tionships is not clearly demonstrated. Most grains are similar to the one illustrated in figure 6. They have equant or prismatic cores of clear orthopyroxene free of visible exsolution lamellae; these cores either are overgrown directly by pigeonite, or are overgrown by orthopyroxene with abundant $\{100\}$ augite exsolution lamellae that is in turn overgrown by pigeonite. Contacts of lamella-free and lamellarich orthopyroxene with each other and with pigeon-

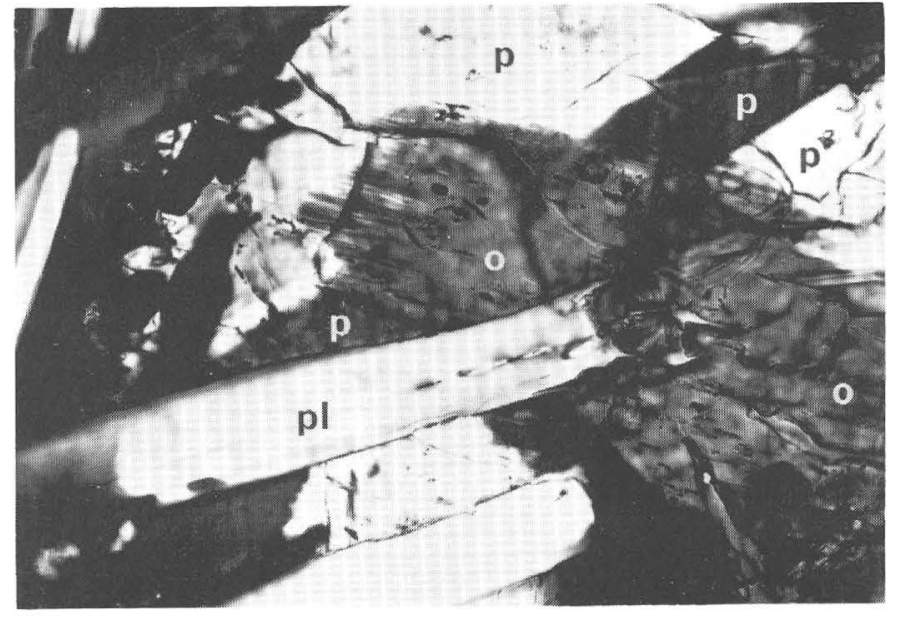

Figure 6.-Photomicrograph of composite orthopyroxenepigeonite grain. Orthopyroxene forms a core (o), one end of which contains $\{100\}$ exsolution lamellae of augite, encased in pigeonite $(p)$. The orthopyroxene is intergrown near its center with the marginal zones of a plagioclase lath $(\mathrm{pl})$ that contains a euhedral core. Width of field of view is $0.35 \mathrm{~mm}$; crossed polarizers.

ite are generally abrupt; commonly subhedral outlines are suggested by the shapes of the contacts, but just as commonly not. In a very small number of grains, the cores of orthopyroxene have textures that indicate they formed by direct inversion of surrounding pigeonite with no accompanying exsolution of augite (fig. 7) ; these grains are rare, however.

Universal-stage data on crystallographic orientations of the two pyroxenes in single composite grains are consistent with inferences drawn from texture as to which orthopyroxenes are primary and which are inverted. In most composite grains, the corresponding crystallographic planes and axes of the orthopyroxene and pigeonite are only very roughly near coincidence. Generally the two pyroxenes have $c$ axes about $10^{\circ}-20^{\circ}$ apart and their $\{010\}$ planes range from nearly coincident to $45^{\circ}$ apart. These departures from structural coincidence indicate that the cores cannot represent orthopyroxene that has inverted from enclosing pigeonite. In the grain with the inverted core illustrated in figure 7 , however, $c$ axes and $\{010\}$ planes of the orthopyroxene and pigeonite are coincident within the error of measurement.

\section{COARSE POLYSYNTHETICALLY TWINNED PIGEONITE}

Locally, the rock contains large, polysynthetically twinned grains of pigeonite that envelop plagioclase grains rather than fill interstices between them (fig. $8)$; the intergrowth with plagioclase tends to be 


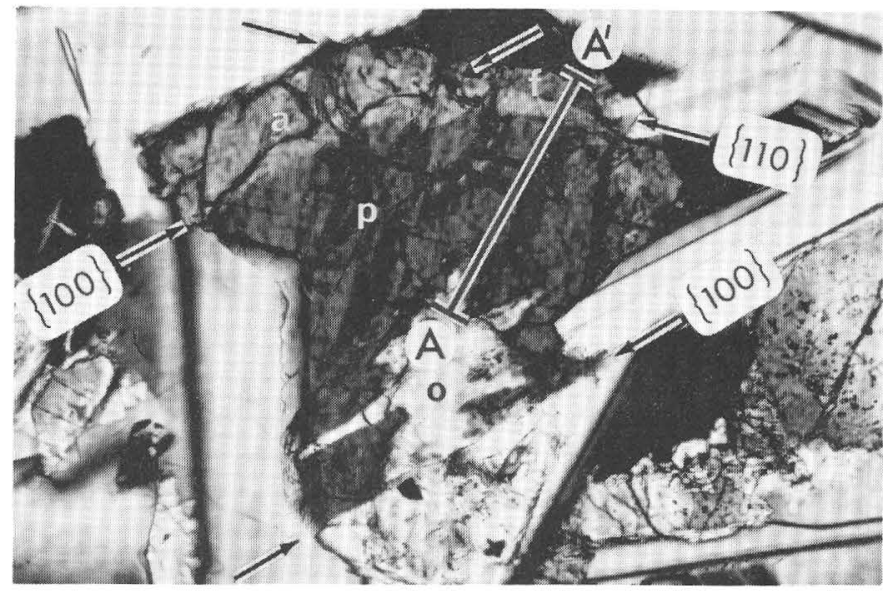

Figure 7.-Photomicrograph of composite orthopyroxenepigeonite-augite grain. The orthopyroxene core (o) formed by inversion of enclosing pigeonite $(p)$; it has a ragged spiked contact and shows elongations parallel to a $\{100\}$ twin composition plane of the pigeonite (marked on photomicrograph). Rotation of the grain by Universal stage reveals that the core is actually a patch of thin laminae parallel to $\{100\}$ of enclosing pigeonite; $c$ axes and $\{010\}$ planes in the orthopyroxene and pigeonite coincide within the error of measurement. Augite (a) forms an epitaxial overgrowth on the central pigeonite; contacts with the pigeonite are planar and parallel to $\{110\}$ and $\{100\}$ (marked on photomicrograph). The augite is in turn overgrown by ferriopigeonite (f). The line $A-A^{\prime}$ indicates the trace of a microprobe profile for which compositional data are plotted on figure 12. Width of field of view is $0.58 \mathrm{~mm}$; crossed polarizers.

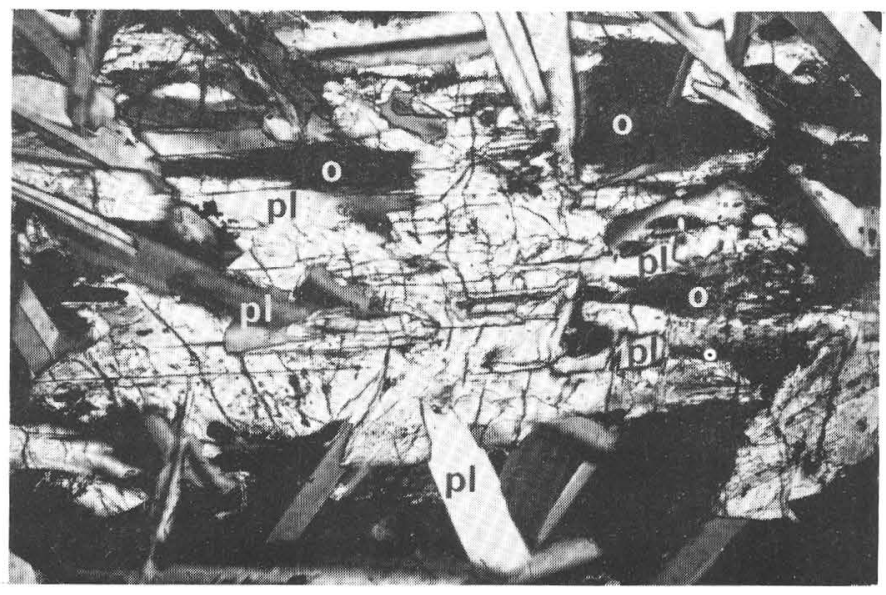

Figure 8.-Photomicrograph of coarse polysynthetically twinned grain of pigeonite. Traces of twin composition planes are dark lines trending east-west. The grain is graphically intergrown with plagioclase $(\mathrm{pl})$, and borders a vug (black, lower right). Around its margin it contains elongate patches of orthopyroxene (o) in optical continuity with one another, suggesting a possible inversion relationship between the two pyroxenes. The orthopyroxene patch at far right contains minute exsolved blebs of augite (white). Width of field of view is $0.88 \mathrm{~mm}$; crossed polarizers. graphic, like typical orthopyroxene-plagioclase intergrowth, rather than subophitic. Most of these pigeonites also have cores of, or are intergrown with, orthopyroxene, and in some cases the texture of the intergrowth suggests a possible inversion relationship between the two pyroxenes (fig. 8). These coarse pigeonite grains commonly occur near vugs.

\section{Ni-Fe, SCHREIBERSITE, AND TROILITE}

The schreibersite-bearing particles in 14310 are of special interest because the presence of such particles has been cited as indicating an impact melting origin for the 14310 magma (Dence and others, 1972). Most of the schreibersite in the rock occurs intergrown with $\mathrm{Ni}-\mathrm{Fe}$ metal and troilite forming composite particles in interstices. The larger of these Fe-Ni-P-S particles (as much as $300 \mu \mathrm{m}$ across) tend to have roughly spherical outlines. Some of the smaller ones, those less than $100 \mu \mathrm{m}$ across, are also globular, but most tend to be less regular in outline and more molded against the edges of grains of adjacent silicate minerals. The particles are not uniformly distributed throughout the rock but tend to occur in scattered concentrations.

Relative proportions of constituent minerals in schreibersite-bearing particles are highly variable. In particles greater than $100 \mu \mathrm{m}$ across, Ni-Fe is dominant and troilite and schreibersite are subordinate; maximum proportions of the latter two minerals observed were 20 and 11 percent by volume, respectively. However, some particles less than 100 $\mu \mathrm{m}$ across contain much more schreibersite than this, and a few were observed in which schreibersite is more abundant than $\mathrm{Ni}-\mathrm{Fe}$.

Figure 9 illustrates the textures of large schreibersite-bearing globules. Central areas of the globules are $\mathrm{Ni}-\mathrm{Fe}$ that is generally free of inclusions of other phases fig. $(9 B)$. In a few particles, however, the metal contains stubby lamellae of schreibersite (fig. 9A); these lamellae typically show common orientations throughout a given particle, indicating that the $\mathrm{Ni}-\mathrm{Fe}$ host is a single crystal. Most schreibersite, however, is concentrated at the edges of particles, forming thin discontinuous rinds. Troilite is wholly restricted to the margins of the globules, where it forms highly irregular grains. In most of these particles, textures and bulk compositions are such that the schreibersite could have been entirely held in solid solution in the coexisting metal, but in a few of the large particles the textures and bulk compositions provide evidence for precipitation of phases from metal-rich melt (see fig. 9A). In smaller similar particles that are very rich in schrei- 

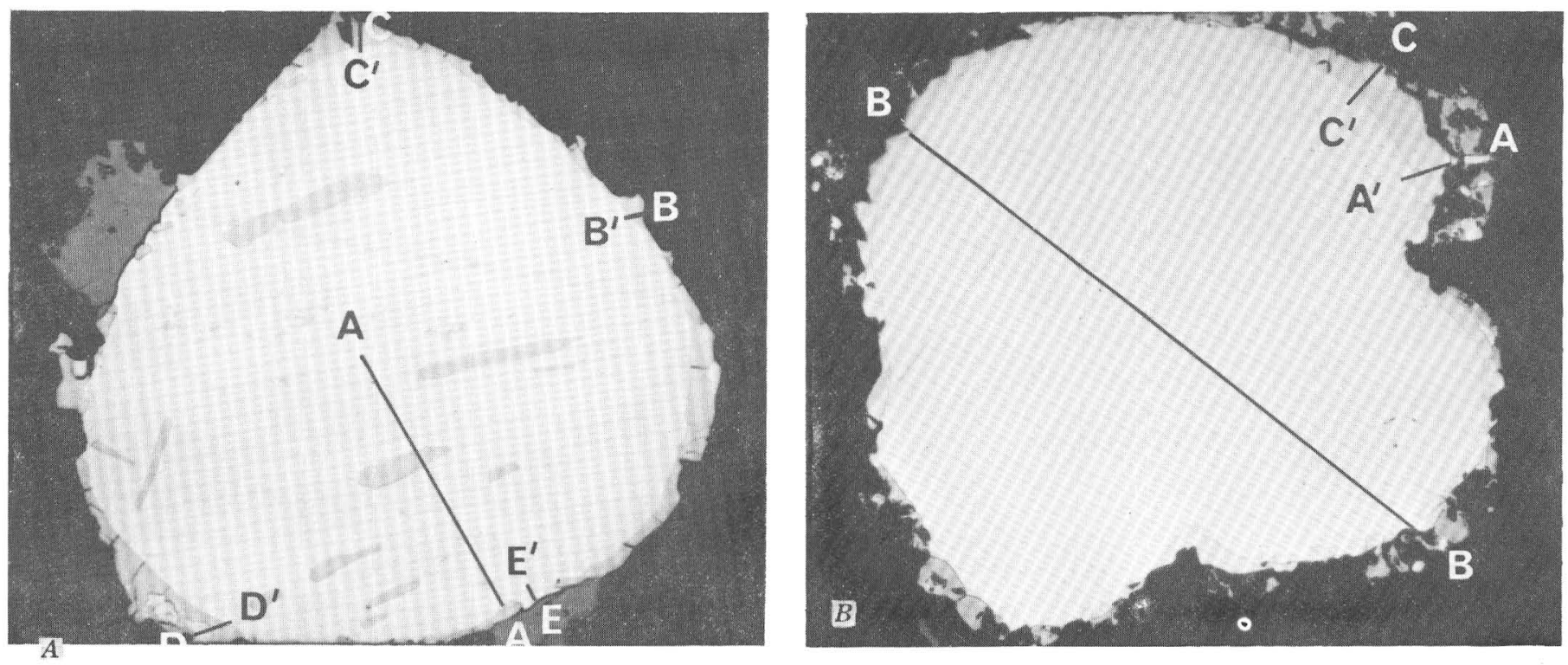

FIGURE 9.-Photomicrographs of large composite globules of Ni-Fe, schreibersite, and troilite. Schreibersite (intermediate gray) forms lamellae within, and marginal grains surrounding, Ni-Fe (light gray). Troilite (dark gray) forms irregular grains at the edges of the particles. $A$, Particle showing charcteristics of precipitation from metal-rich melt. Textural evidence for precipitation from melt is the presence of eutectoid blebs of $\mathrm{Ni}-\mathrm{Fe}$ within marginal schreibersite (lower left). Compositional evidence is that the bulk particle contains about 2.3 percent by weight phosphorus (calculated using averaged microprobe analyses of phases and areal phase proportions converted to volume proportions); this much phosphorus could not have been entirely held in solid solution in the associated metal (Doan and Goldstein, 1969). The lamellae of schreibersite within the $\mathrm{Ni}-\mathrm{Fe}$ formed by exsolution, and the marginal schreibersite that precipitated from melt was probably also augmented by exsolution. The line marked $A-A$ indicates the trace of a microprobe profile for which compositional data are plotted on figures 20 and 21 . Short lines marked $B-B^{\prime}, C-C^{\prime}, D-D^{\prime}$, and $E-E^{\prime}$ indicate the positions of traverses for which compositional data are plotted on figure $21 \mathrm{~A}$. Width of field of view is $0.36 \mathrm{~mm}$; reflected light, oil immersion. $B$, Large composite particle free of schreibersite exsolution lamellae. No textural evidence for precipitation from melt is apparent, and bulk composition is such that all phosphorus could have initially been held in solid solution in the metal. The line marked $B-B$ indicates the trace of a microprobe profile for which compositional data are plotted on figure 20. Short lines marked $A-A^{\prime}$ and $C-C^{\prime}$ indicate the positions of traverses for which compositional data are plotted on figure $21 \mathrm{~B}$. Width of field of view is $0.44 \mathrm{~mm}$; reflected light, oil immersion.

bersite, textures are also suggestive of precipitation from metal-rich melt: these textures are very like those of the metal-troilite particles that crystallized from $\mathrm{Fe}-\mathrm{Ni}-\mathrm{S}$ melt immiscible in Apollo 11 basaltic magma (Skinner, 1970).

Mesostasis immediately surrounding many of the large schreibersite-bearing particles contains more abundant grains of apatite and whitlockite than elsewhere in the rock. Typically the grains of phosphate minerals are clustered along the edges of the $\mathrm{Fe}-\mathrm{Ni}-\mathrm{P}-\mathrm{S}$ particles and border metal with no intervening schreibersite. Phosphate minerals also form broad reaction rims bordering the few schreibersitebearing particles that occur within or near finegrained clots (fig. $2 D$ ).

Particles in which $\mathrm{Ni}-\mathrm{Fe}$ and troilite occur singly or together without schreibersite are more abundant than the schreibersite-bearing particles. They are, however, mostly less than about $20 \mu \mathrm{m}$ across, al- though a few are present that are as much as 120 $\mu \mathrm{m}$ across. Generally either troilite or $\mathrm{Ni}-\mathrm{Fe}$ is strongly dominant in a given particle, and particles in the size range $20-120 \mu \mathrm{m}$ almost all have dominant Ni-Fe. Most commonly the particles are irregular and interstitial ; less commonly they have spherical outlines, and very rarely they are euhedral.

$\mathrm{Ni}-\mathrm{Fe}$, troilite, and schreibersite all occur as inclusions in plagioclase and pyroxene; individual inclusions may consist of any of these phases either singly or in combination. The inclusions in plagioclase were studied in detail in order to determine the approximate point in the crystallization sequence when a metal-bearing phase first appeared in the silicate melt. Most of these inclusions are rounded droplets about $5 \mu \mathrm{m}$ across, but a few are globules as large as $30 \mu \mathrm{m}$ across (fig. 10). The inclusions tend to be concentrated along twin composition planes in the host feldspar. 

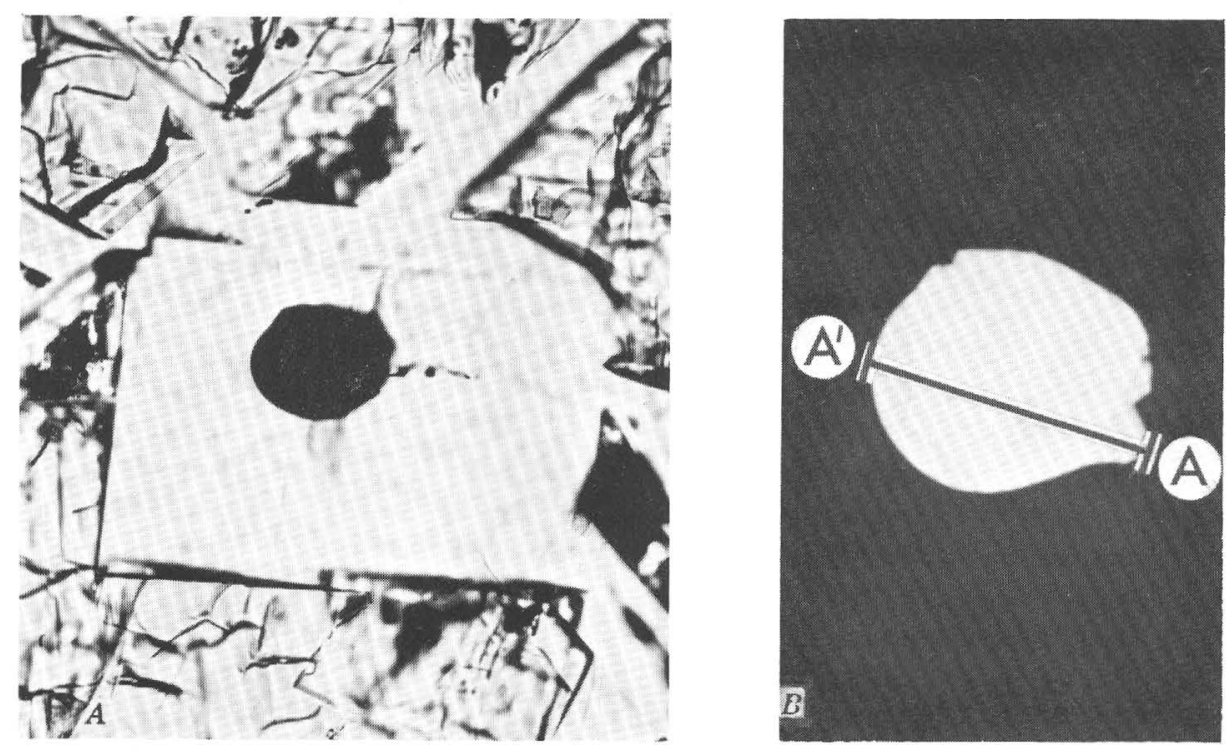

FIGURE 10.-Photomicrographs of globule of $\mathrm{Ni}-\mathrm{Fe}+$ schreibersite included in plagioclase. $A, \mathrm{Fe}-\mathrm{Ni}-\mathrm{P}$ globule (black) enclosed by euhedral feldspar. Width of field of view is $0.19 \mathrm{~mm}$; plane-polarized light. $B$, Inclusion photographed with reflected light. $\mathrm{Ni}-\mathrm{Fe}$ is white, schreibersite is gray. The line marked $A-A^{\prime}$ indicates the trace of a microprobe profile for which compositional data are plotted on figure 22 . Width of field of view is $0.07 \mathrm{~mm}$.

\section{PHASE COMPOSITIONS}

Average compositions of plagioclase and pyroxene in 14310 have been estimated from the results of chemical-mode calculations (method described by Wright and Doherty, 1970). The chemical modes were calculated using $\mathrm{An}_{95}$ and $\mathrm{An}_{75}$ as end member plagioclases, and magnesian orthopyroxene, magnesian augite, and pyroxferroite as end member pyroxenes (with $\mathrm{Al}_{2} \mathrm{O}_{3}$ and $\mathrm{TiO}_{2}$ contents in the latter three minerals assigned on the basis of electron microprobe analyses of typical grains). Rock analyses used were those reported by Kushiro and others (1972), Rose and others (1972), and Compston and others (1972a). The calculated average plagioclase composition is a calcic bytownite, $\mathrm{Or}_{1,2} \mathrm{Ab}_{10,0} \mathrm{An}_{88,8}$, and the calculated average bulk pyroxene composition is a pigeonite, $\mathrm{Wo}_{10.9} \mathrm{En}_{58.0} \mathrm{Fs}_{31.1}$.

Electron-microprobe analyses were made in order to determine the nature of compositional variations in important phases throughout the crystallization sequence. Most of the analyses were not complete. Plagioclase was analyzed only for $\mathrm{Ca}, \mathrm{K}$, and $\mathrm{Na}$, and potassium feldspar for $\mathrm{Ca}, \mathrm{K}, \mathrm{Na}$, and $\mathrm{Ba}$; standards were chosen sufficiently close in composition to the unknowns that only background corrections were necessary. Pyroxenes were analyzed only for $\mathrm{Ca}, \mathrm{Mg}$ and $\mathrm{Fe}$, and the raw data were corrected using the correction program of Boyd and others (1969), with contents of minor elements and
Si assigned on the basis of a few complete analyses performed on typical grains. (For data on $\mathrm{Al}_{2} \mathrm{O}_{3}$, $\mathrm{TiO}_{2}$, and $\mathrm{Cr}_{2} \mathrm{O}_{3}$ contents of pyroxenes, the reader is referred to papers by Kushiro and others, 1972, Ridley and others, 1972, Brown and others, 1972, Bence and Papike, 1972, and Hollister, 1972.) Ni-Fe and schreibersite were analyzed for $\mathrm{Ni}, \mathrm{Co}$, and $\mathrm{P}$. The $\mathrm{Ni}$ and $\mathrm{Co}$ intensity values, corrected for background, were assumed to vary linearly with content of these elements in both unknowns and standards. Phosphorus was determined only semiquantitatively.

\section{PLAGIOCLASE}

Subhedral laths of all sizes were analyzed and the zoning variations in the larger laths were studied in detail in order to determine the pattern of overall compositional variation during the crystallization history. The results of these analyses, presented below, show an orderly progressive change of compositions that provide a rough scale against which it is possible to calibrate points of appearance of, and compositional changes within, coprecipitating phases. To determine points of first precipitation of orthopyroxene and coarse polysynthetically twinned pigeonite, analyses were made of plagioclase included within and graphically intergrown with these pyroxenes. Plagioclase enveloping particles of $\mathrm{Ni}-\mathrm{Fe}$ \pm schreibersite \pm troilite was analyzed to determine points of appearance of these phases. Edges of laths bordering vugs were analyzed to determine at what 
approximate point in the crystallization sequence open vugs formed, and laths in fine-grained clots were analyzed to determine their compositional relationships to feldspar elsewhere in the rock.

\section{SUBHEDRAL LATHS}

Compositions within laths analyzed in this study range from $\mathrm{An}_{97}$ to $\mathrm{An}_{62}$. Cores of grains tend to be at the more calcic end of this range, and rims tend to be at the more sodic end, but the extent of zoning varies considerably from grain to grain. Other investigators have reported similar values, and all data fall within an overall range of $A n_{98}$ to $A n_{58}$ (Dence and others, 1972; Kushiro and others, 1972; Walter and others, 1972; Brown and Peckett, 1971; Longhi and others, 1972; Trzcienski and Kulick, 1972; Ridley and others, 1972). Trace element contents were reported by Trzcienski and Kulick (1972).

Large $(>300 \mu \mathrm{m})$ subhedral laths analyzed here have cores that are about $A n_{94-95}$ and edges adjacent to mesostasis glass that are about $\mathrm{An}_{65-71}$. The overall compositional change is normal progressive zoning with superimposed minor oscillatory zoning. Figure 11 presents microprobe profiles across three large subhedral laths. In these grains the compositional oscillations represent about 2 percent An content at a maximum. No major reversals in zoning are observed, but the grains analyzed all show a consistent dip in $\mathrm{Na}_{2} \mathrm{O}$ content at about one-quarter the distance from center to edge.

Zoning in intermediate-sized $(75-300 \mu \mathrm{m})$ subhedral laths is much like in larger laths. The grains analyzed in this study have cores as calcic as $\mathrm{An}_{93.5}$ and rims adjacent mesostasis as rich in $\mathrm{K}$ and $\mathrm{Na}$ as $\mathrm{Or}_{5,0} \mathrm{Ab}_{32.5} \mathrm{An}_{62.5}$. Slight oscillatory zoning is present, and again there is no significant reverse zoning.

Only a few small $(<75 \mu \mathrm{m})$ laths in mesostasis glass were analyzed here, and their compositions cover virtually the entire range of An content observed in larger grains- $\mathrm{An}_{94}$ to $\mathrm{An}_{62}$. Most, however, are in the range $A n_{62}$ to $A n_{i s}$, and one tiny core of plagioclase within a potassium feldspar grain has the composition $\mathrm{Or}_{5.0} \mathrm{Ab}_{2 \pi .9} \mathrm{An}_{6 \tau .1}$.

Brown and Peckett (1971) and Ridley and others (1972) analyzed large and intermediate-sized zoned laths similar to those studied here and found similar ranges of composition, cores of $\mathrm{An}_{95-94}$ and rims of $\mathrm{An}_{i 2-58}$. Ridley and others further reported analyses of laths that were unzoned or asymmetrically zoned; unfortunately these authors did not describe the phases bordering such grains, so crystallization histories cannot be evaluated. Kushiro and others (1972) and Ridley and others (1972), respectively, reported that compositions of small laths associated with mesostasis are $\mathrm{An}_{84-i 4}$ and $\mathrm{An}_{91-81}$. Brown and Peckett (1971) analyzed microlaths of $\mathrm{An}_{94.5-91}$ in their samples, but whether or not these grains bordered glass was not specified.

\section{GRAINS ENCLOSING METAL-SCHREIBERSITE- TROILITE INCLUSIONS}

Ten grains of plagioclase enclosing particles of $\mathrm{Ni}-\mathrm{Fe}$ metal \pm schreibersite \pm troilite were analyzed in this study. Plagioclase directly impinging on the inclusions ranges from $\mathrm{An}_{88.0}$ to $\mathrm{An}_{95.7}$ and averages $A n_{93.5 .}$ (Plagioclase enveloping the globule shown in fig. 10 is $\mathrm{An}_{93.7}$. ) Microprobe traverses from core to edge of two feldspar laths that contain $\mathrm{Ni}-\mathrm{Fe}$ inclusions show that the plagioclase at the same "stratigraphic" horizon as the inclusions is about $\mathrm{An}_{94}$.

\section{LATHS ADJACENT TO VUGS}

The plagioclase at the extreme edges of two laths bordering vugs is $\mathrm{An}_{80.1}$ and $\mathrm{An}_{\bar{i} 4.4}$.

\section{LATHS IN FINE-GRAINED CLOTS}

Plagioclase grains in clots in which mesostasis minerals are absent have quite calcic compositions. In the three clots studied, all grains analyzed average about $\mathrm{An}_{95-96}$; the most sodic plagioclase found is $\mathrm{An}_{86}$, at the extreme edge of one lath. (Walter and others, 1972, found an identical compositional range for plagioclase in a clot they studied, $\mathrm{An}_{96-85}$, and Kushiro and others, 1972, reported $\mathrm{An}_{92}$ in a clot they studied.)

\section{ORTHOPYROXENE}

Most orthopyroxene grains analyzed in this study have compositions in the range $\mathrm{Wo}_{4} \mathrm{En}_{79} \mathrm{Fs}_{17}$ to $\mathrm{Wo}_{5} \mathrm{En}_{65} \mathrm{Fs}_{30}$ and are zoned from more magnesian at their centers to more iron rich at their edges. In a few grains, thin marginal zones less than $10 \mu \mathrm{m}$ wide show stronger iron enrichment, with Fs content as much as 40 percent (see profile $B-B^{\prime}$, fig. 12 ). Other workers (Ridley and others, 1972; Brown and Peckett, 1971; Ringwood and others, 1972; Hollister and others, 1972; Kushiro, 1972; and Takeda and Ridley, 1972) reported similar ranges or analyses within this range. Compositional variations associated with specific textures are presented in detail below.

\section{ORTHOPYROXENE WITH PRESERVED EUHEDRAL CRYSTAL FACES}

Grains that retain traces of euhedral growth surfaces were studied in detail because their textures 
Profile A
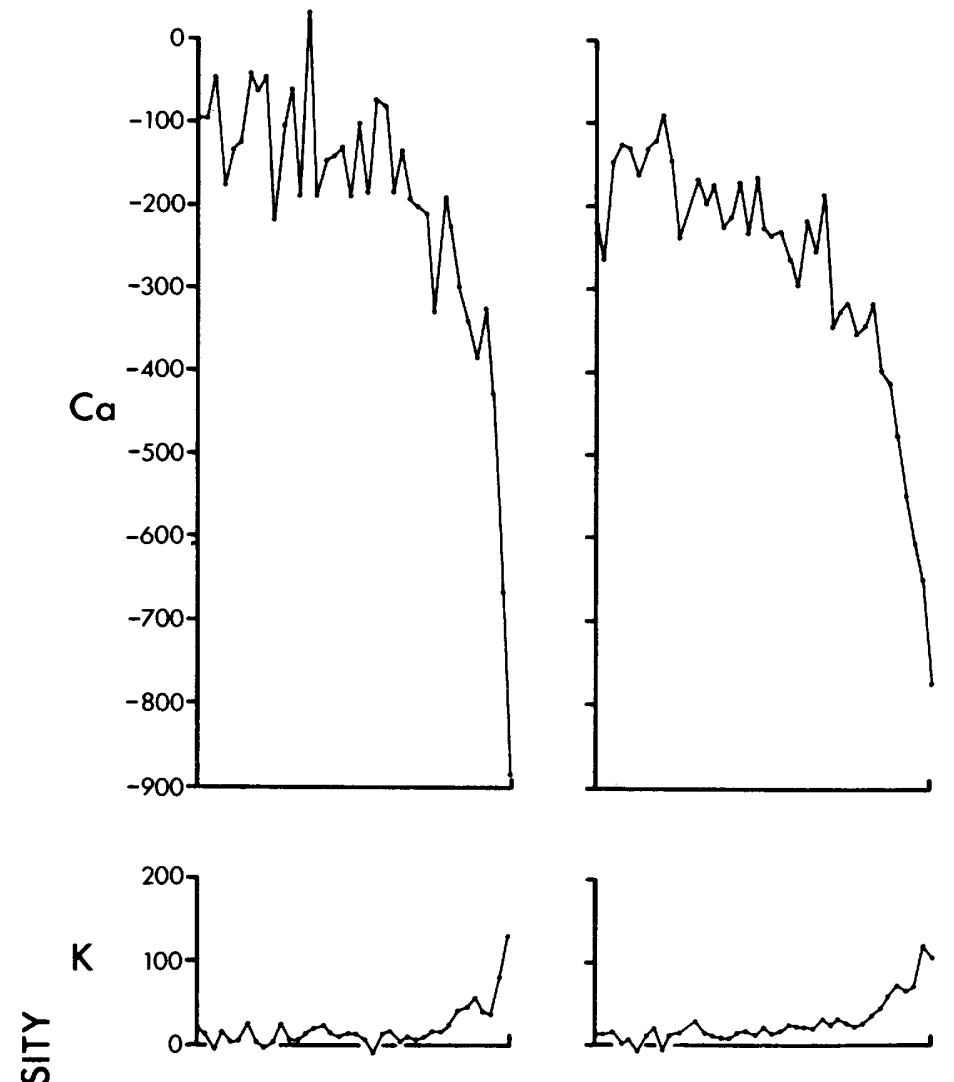

$\underline{\underline{Z}}$



Profile B
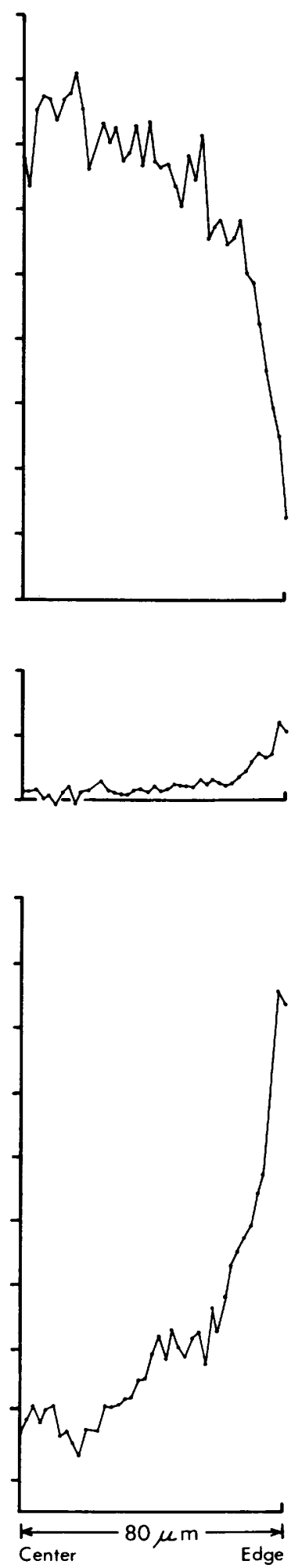
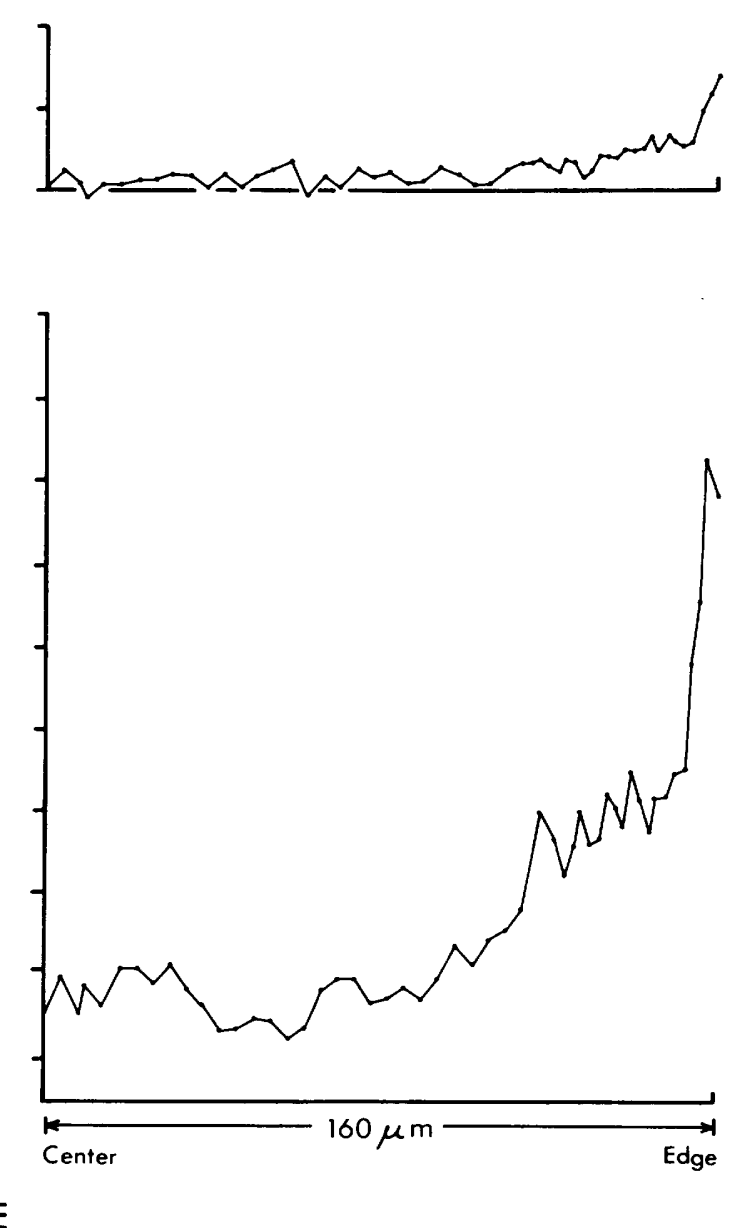

\section{Distance}

Profile C

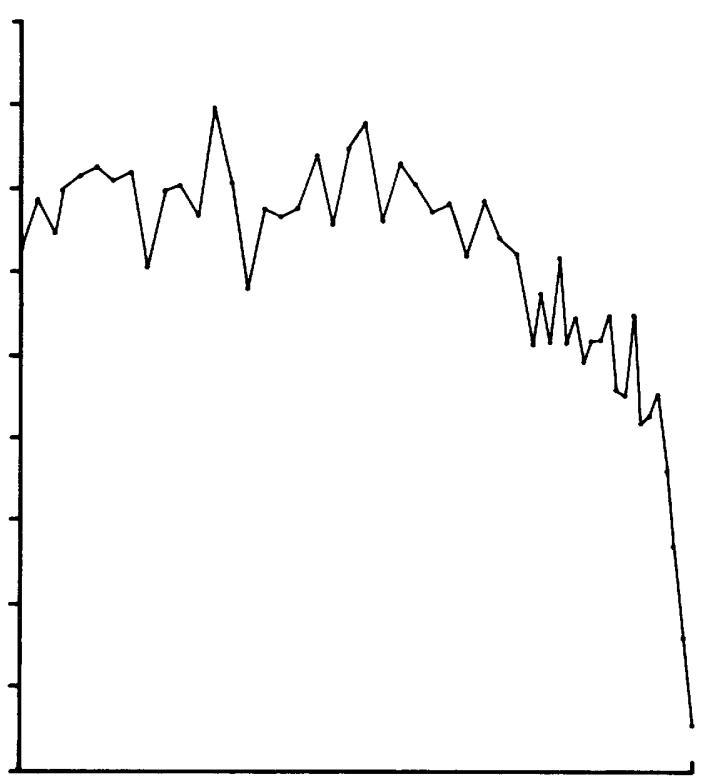


FIgURE 11.-Variations in $\mathrm{Ca}, \mathrm{K}$, and $\mathrm{Na}$ contents along profiles from centers to edges bordering mesostasis of three different large plagioclase laths. Points were analyzed at $2-\mu \mathrm{m}$ intervals. Ordinates represent intensity of X-rays generated by electron bombardment in an electron microprobe; units are counts per constant increment of beam current, and the scale is relative to pure anorthite for $\mathrm{Ca}$ and to background for $\mathrm{K}$ and $\mathrm{Na}$. For reference, a point with $0 \mathrm{Ca}$ and $0 \mathrm{Na}$ would be pure anorthite, and a point with $-800 \mathrm{Ca}$ and $+800 \mathrm{Na}$ would be about $\mathrm{An}_{71}$. Abscissas represent linear distance. All grains show zones slightly depleted in $\mathrm{Na}_{2} \mathrm{O}$ at about one-quarter the distance from center to edge, minor oscillations throughout their interiors, and margins abruptly enriched in $\mathrm{K}$ and $\mathrm{Na}$.

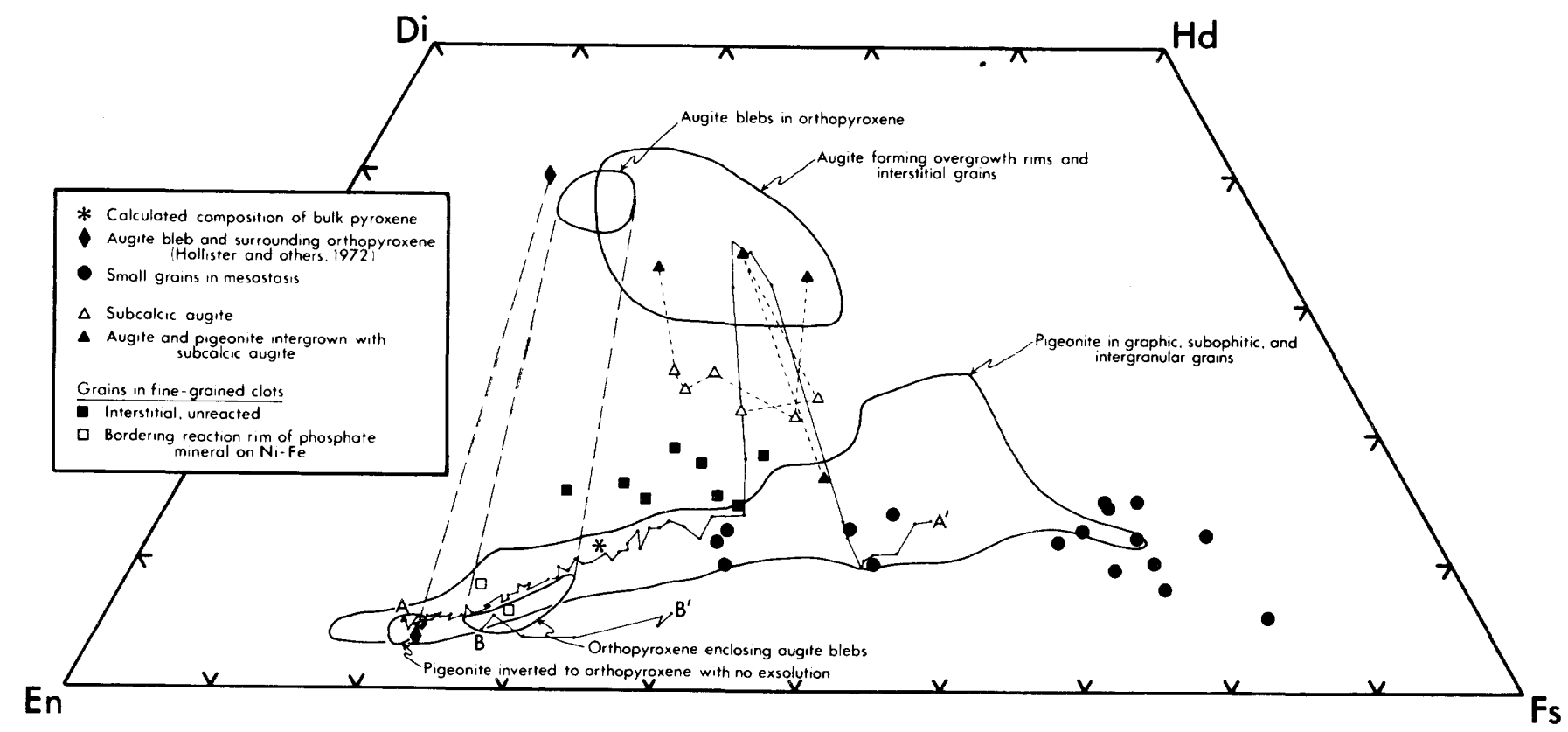

FIGURE 12.-Wo:En:Fs contents of pyroxenes analyzed in this study. For comparison the composition of bulk pyroxene calculated from chemical mode computations is also plotted. Heavy solid lines outline fields of compositions of pyroxenes of specific textural types. Long-dashed lines connect compositions of augite blebs with compositions of orthopyroxene that encloses them. Light solid lines connect points analyzed at $2-\mu \mathrm{m}$ intervals along profiles across two grains. $A-A^{\prime}$ is a profile across the composite orthopyroxene-pigeonite-augite grain illustrated in figure 7 , beginning just within the core of inverted orthopyroxene, crossing the inner pigeonite zone, the augite epitaxially overgrown on the pigeonite, and the outer rim of ferropigeonite, and ending at the grain margin. $B-B^{\prime}$ is a profile across a $12-\mu$ m-wide marginal zone of an orthopyroxene grain that shows strong iron enrichment at its extreme edge $\left(B^{\prime}\right)$. Short-dashed lines connect compositions of adjacent points in intergranular grains that consist of complexly intergrown augite, ferropigeonite, and subcalcic augite.

suggest that they might represent the earliest crystallized mafic minerals in the rock; furthermore, the observation that these grains contain glassy inclusions that were trapped periodically during their crystallization suggests that the pyroxene compositions might show the effects of periodic fluctuations in volatile content or temperature in the melt. Four such pyroxene grains were analyzed. They have average compositions about $\mathrm{Wo}_{4.5} \mathrm{En}_{73-78} \mathrm{Fs}_{18-22}$, in the more magnesian part of the orthopyroxene range. The zoning patterns are indeed unusual: All grains show complex oscillatory variations of $\mathrm{Fe} / \mathrm{Mg}$ ratio, and some show reverse zoning as well, small cores being as iron rich as $\mathrm{Fs}_{29}$.

In two of the grains, euhedral cores are outlined by inclusion-rich planes but are themselves relatively inclusion free. Figure 3 illustrates one of these grains, and figures 13 and 14 show the compositional variations it exhibits. The euhedral core contains one band about $15 \mu \mathrm{m}$ wide with about 1 percent greater Fs content than the rest of the core (see profile A, figs. 13 and 14). In the other similar grain analyzed, adjacent bands in the core differed by as much as 11 percent in Fs content.

The other two grains analyzed show traces of euhedral outlines throughout their interiors, and these lines clearly define the nuclei of the grains and their growth directions. Figures $4 A$ and $5 A$ illustrate these grains, and figure 15 (profile A) shows the compositional variations across the first of them. The nucleus of the grain is about $\mathrm{Wo}_{-} \mathrm{En}_{67} \mathrm{Fs}_{\mathrm{S}_{28}}$ and shows reverse zoning to $\mathrm{Wo}_{4} \mathrm{En}_{i 6} \mathrm{Fs}_{20}$. The rernainder 

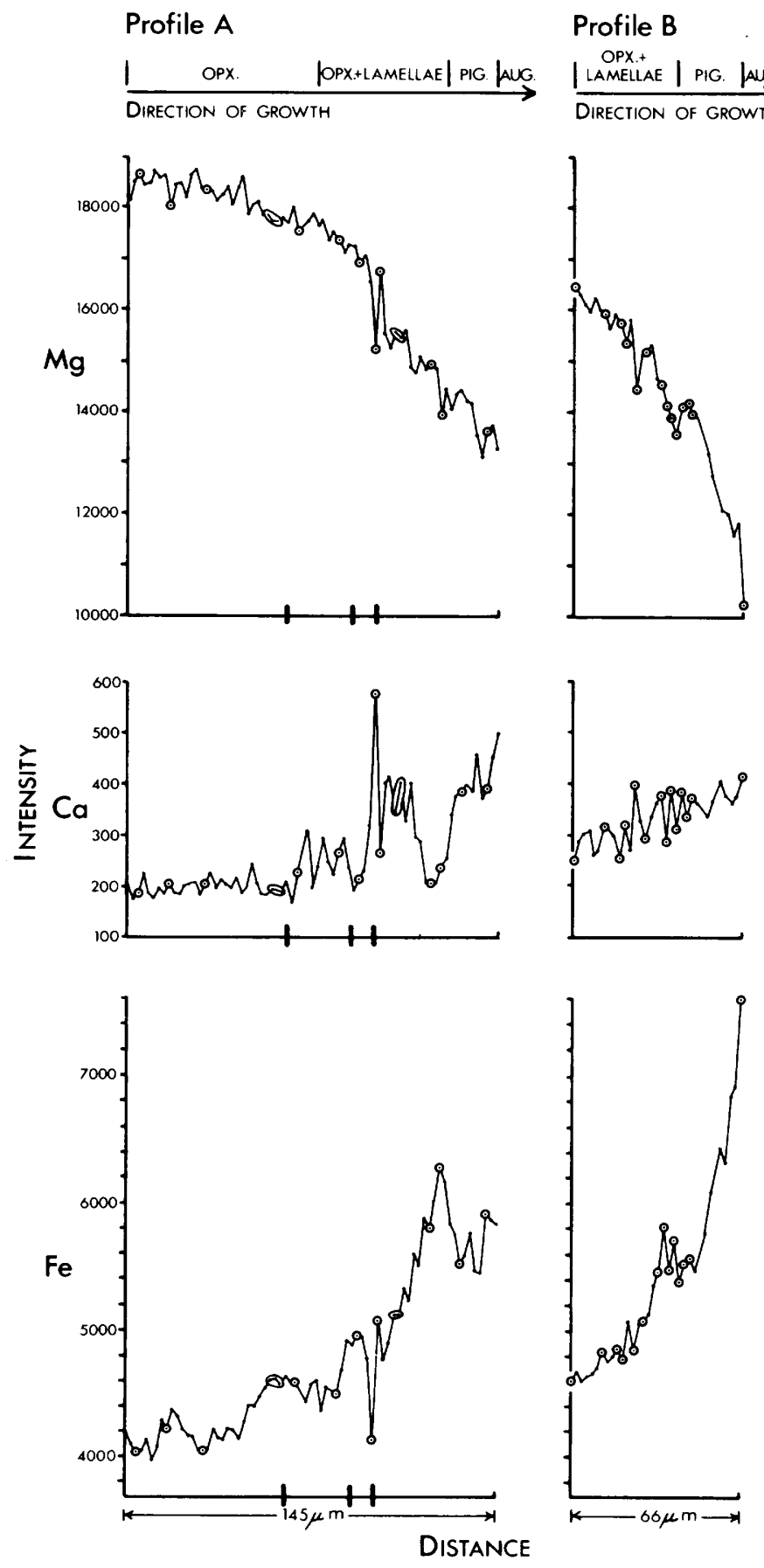

of the grain averages about this latter composition but shows pronounced oscillatory zoning, with alternating bands several micrometers thick differing by about 1.5 percent in Fs content.

\section{ORTHOPYROXENE ADJACENT TO VUGS}

A grain of orthopyroxene bordering a vug was analyzed to determine whether or not its composition was affected by local variations in volatile con-
Figure 13.-Variations in $\mathrm{Mg}$, $\mathrm{Ca}$, and $\mathrm{Fe}$ contents along profiles across the composite orthopyroxene-pigeoniteaugite grain pictured in figure 3 . Profiles $A$ and $B$ correspond to profiles $A-A$ and $B-B$ marked on figure 3. Ordinates represent intensity of $\mathrm{X}$-rays generated by electron bombardment in an electron microprobe; units are absolute numbers of counts per constant increment of beam current. Abscissas represent linear distance. Growth directions in the grain and positions of boundaries between phases are indicated above profiles; vertical lines on abscissas mark the positions of inclusion-rich planes. Wo: En:Fs contents of circled points are plotted on figure 14. The orthopyroxene core (profile A) shows oscillatory and normal progressive zoning. For the surrounding zone where the orthopyroxene contains abundant exsolved augite lamellae, compositions of the two phases are best resolved in data obtained in profile $\mathrm{A}$, whereas composition of the primary pyroxene is approximated in data obtained in profile $B$.

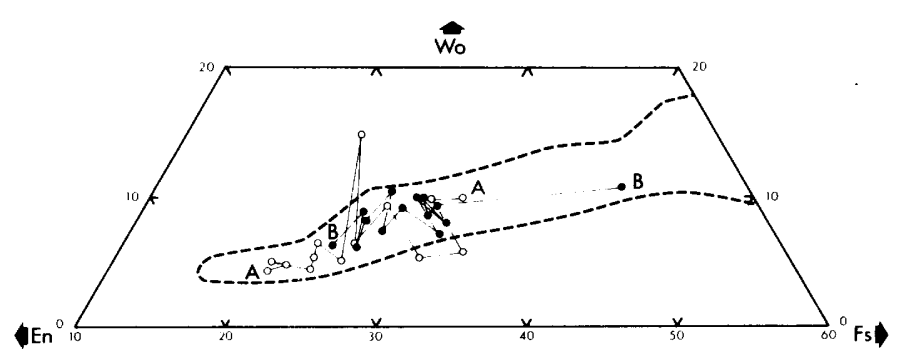

FIGURE 14.-Wo:En:Fs contents of points on the profiles plotted on figure 13. Open circles are points on profile $A$; solid circles are points on profile B. Light solid lines connect consecutive points on the profiles. For comparison, the heavy dashed line outlines the boundary of the field of compositions of pigeonite in graphic, subophitic, and intergranular grains from figure 12.

tent associated with vug formation. The grain is illustrated in figure $4 B$, and the compositional variations it shows in a profile from its center to its edge are plotted in figure 15 (profile B). The grain shows alternating reverse and normal zoning that combine to produce broad oscillatory variations in $\mathrm{Fe} / \mathrm{Mg}$ ratio in bands parallel to the vug edge. At its core, the orthopyroxene is $\mathrm{Wo}_{5} \mathrm{En}_{i 1} \mathrm{Fs}_{\mathrm{S}_{4}}$; in the direction of the vug the grain shows reverse zoning to $\mathrm{Wo}_{4} \mathrm{En}_{i 7} \mathrm{Fs}_{19}$ and then normal progressive zoning to $\mathrm{Wo}_{4} \mathrm{En}_{73} \mathrm{Fs}_{\mathrm{S}_{23}}$. Orthopyroxene of this composition is rimmed by orthopyroxene of similar composition but different extinction position; the rim orthopyroxene shows reverse zoning to $\mathrm{Wo}_{1} \mathrm{En}_{i \bar{s}} \mathrm{Fs}_{18}$ followed by normal zoning to $\mathrm{Wo}_{5} \mathrm{En}_{71} \mathrm{Fs}_{\mathrm{S}_{24}}$. Orthopyroxene of this latter composition is in turn overgrown by pigeonite, which forms a $10-\mu \mathrm{m}$-thick rim directly bordering the vug and is normally zoned from $\mathrm{Wo}_{7} \mathrm{En}_{6}-\mathrm{Fs}_{\mathrm{S}_{26}}$ to $\mathrm{Wo}_{10} \mathrm{En}_{50} \mathrm{Fs}_{\mathrm{S}_{40}}$. 


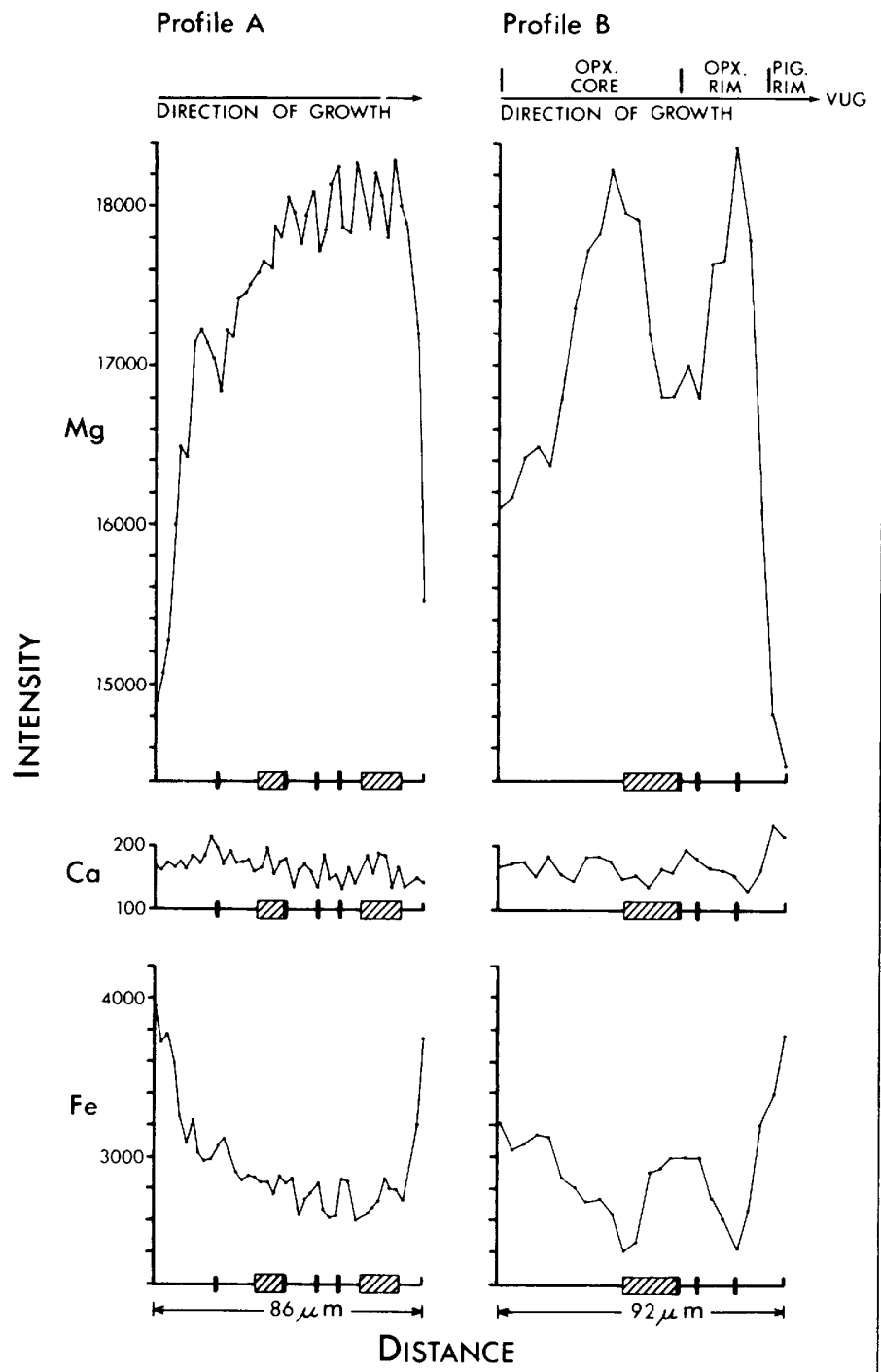

Figure 15.-Variations in $\mathrm{Mg}, \mathrm{Ca}$, and $\mathrm{Fe}$ contents along profiles across orthopyroxene grains. Ordinate, abscissa, and designations of textural relations are the same as described in the caption to figure 13 , except that, in addition to inclusion-rich planes, inclusion-rich zones are marked on abscissas by patterned boxes. Profile A crosses a grain that shows traces of euhedral growth surfaces throughout its interior (fig. 4A). This grain shows pronounced reverse and oscillatory zoning in $\mathrm{Fe}-\mathrm{Mg}$ contents. Profile $\mathrm{B}$ crosses a grain that borders a vug (fig. $4 B$ ). The grain shows reverse and normal zoning that combine to produce bands of oscillating $\mathrm{Fe} / \mathrm{Mg}$ ratio parallel to the vug edge.

\section{ORTHOPYROXENE CONTAINING BLEBS AND $\{100\}$ LAMELLAE OF AUGITE}

From their textures, these blebs and lamellae all appear to have been exsolved from the enclosing orthopyroxene (see figs. 3, 6, and 8), and the mineral pairs were analyzed to investigate the compositional range in which this exsolution occurred. All such grains of orthopyroxene analyzed in this study are in the more iron-rich part of the compositional range, $\mathrm{Fs}>25$, but Hollister and others (1972) reported finding blebs in a more magnesian orthopyroxene, $\mathrm{Wo}_{4} \mathrm{En}_{74} \mathrm{Fs}_{22}$. (Hollister and others interpreted the blebs they analyzed as inclusions rather than exsolution products. The compositions, however, are reasonable extrapolations of the compositional range of the exsolved blebs analyzed here, and it is likely that all such blebs have the same origin.) The field of compositions of the grains analyzed here, and the analysis reported by Hollister and others, are indicated on figure 12.

Figures 13 and 14 give the compositional data for the grain containing abundant augite lamellae pictured in figure 3 . The present composition of the host orthopyroxene is about $\mathrm{Wo}_{5} \mathrm{En}_{70} \mathrm{Fs}_{\mathrm{S}_{25}}$ to $\mathrm{Wo}_{6} \mathrm{En}_{61} \mathrm{FS}_{33}$ (best resolved in profile A, fig. 13), and the primary pyroxene prior to exsolution appears to have ranged from about $\mathrm{Wo}_{0_{6}} \mathrm{En}_{71} \mathrm{~F}_{\mathrm{S}_{23}}$ to about $\mathrm{Wo}_{9} \mathrm{En}_{62} \mathrm{~F}_{\mathrm{S}_{29}}$ (profile B, fig. 13).

\section{ORTHOPYROXENE FORMED BY INVERSION OF PIGEONITE}

Two orthopyroxene cores that formed by inversion of surrounding pigeonite with no visible exsolution of augite (one is illustrated in fig. 7) were analyzed in order to determine whether or not a compositional change accompanied the inversion. The field of compositions for these cores, and a trace from within one of them across the contact with surrounding pigeonite (profile $A-A^{\prime}$ ) are plotted on figure 12. There is no compositional discontinuity at the contact; the orthopyroxene averages about $\mathrm{Wo}_{4.5} \mathrm{En}_{\overline{74.5}} \mathrm{Fs}_{21}$, and immediately adjacent pigeonite is of similar composition.

\section{COMPOSITION OF ORTHOPYROXENE AND CLINOPYROXENE AT THEIR CONTACTS}

Microprobe traverses were made across contacts of exsolution-free orthopyroxene with pigeonite, and with orthopyroxene that contains abundant exsolution, in order to determine whether or not the textural variations observed are correlated with specific compositional ranges. The data for the 16 composite grains analyzed are shown on figure 16 . There do appear to be several consistent correlations of composition with texture. Orthopyroxene grains that have euhedral outlines (fig. $5 A$ ), contain preserved traces of euhedral outlines (fig. $4 A$ ), or have inverted from pigeonite (fig. 7) are generally more magnesian than $\mathrm{F}_{S_{25}}$ at their edges. In these grains the pigeonite at the contact is typically close in com- 


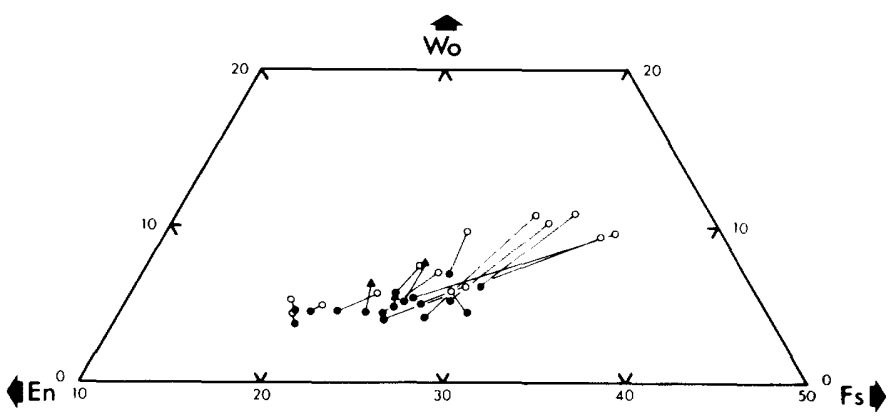

Figure 16.-Wo:En:Fs contents of exsolution-free orthopyroxene, orthopyroxene with augite lamellae, and pigeonite at their contacts. Solid circles are orthopyroxene, solid triangles are orthopyroxene containing abundant augite lamellae, and open circles are pigeonite. Solid lines connect compositions across the contacts, and the points are separated by no more than $6 \mu \mathrm{m}$.

position to the orthopyroxene, and in many grains there is virtually no compositional discontinuity (fig. 17 , profile A). Orthopyroxene cores that are overgrown by orthopyroxene with abundant augite lamellae are around $\mathrm{Fs}_{25}$ at the contact of the two orthopyroxenes; the primary pyroxene in the overgrowth appears to have been appreciably more calcic than the orthopyroxene in the core (figs. 13, 14, and 16). Orthopyroxene cores for which textures do not indicate whether or not they reacted with melt prior to pigeonite precipitation tend to be more iron-rich than $\mathrm{Fs}_{25}$ at their edges, and the compositional transitions across the contacts range from continuous to strongly discontinuous. The one grain analyzed that shows a possible resorbed margin (fig. $5 B$ ) is $\mathrm{Fs}_{\mathrm{S}_{26}}$ at its edge, and the compositional change across the contact is sharply discontinuous with the adjacent pigeonite much depleted in $\mathrm{Mg}$ and enriched in $\mathrm{Ca}$ and $\mathrm{Fe}$ (fig. 17, profile B).

None of the orthopyroxene grains analyzed here are directly rimmed by augite; all have intervening zones at least a few micrometers thick of pigeonite. However, Hollister and others (1972) reported an analysis of an unusually calcic hypersthene, $\mathrm{Wo}_{11} \mathrm{En}_{5 \mathrm{~s}} \mathrm{Fs}_{\mathrm{S}_{31}}$, directly overgrown by augite, $\mathrm{Wo}_{37} \mathrm{En}_{42} \mathrm{Fs}_{21}$.

\section{PIGEONITE AND FERROPIGEONITE}

The pigeonites that form the bulk of the pyroxene grains in the rock have an extremely wide range of $\mathrm{Fe} / \mathrm{Mg}$ ratios but are fairly restricted in $\mathrm{Ca}$ contents. The compositional field of such pigeonites analyzed in this study is outlined on figure 12 (pigeonites in graphic, subophitic, and intergranular grains); other authors report pigeonite compositions within the overall range observed here (Kushiro and others, 1972; Gancarz and others, 1971; Brown and others, 1972). Single grains are in gen-

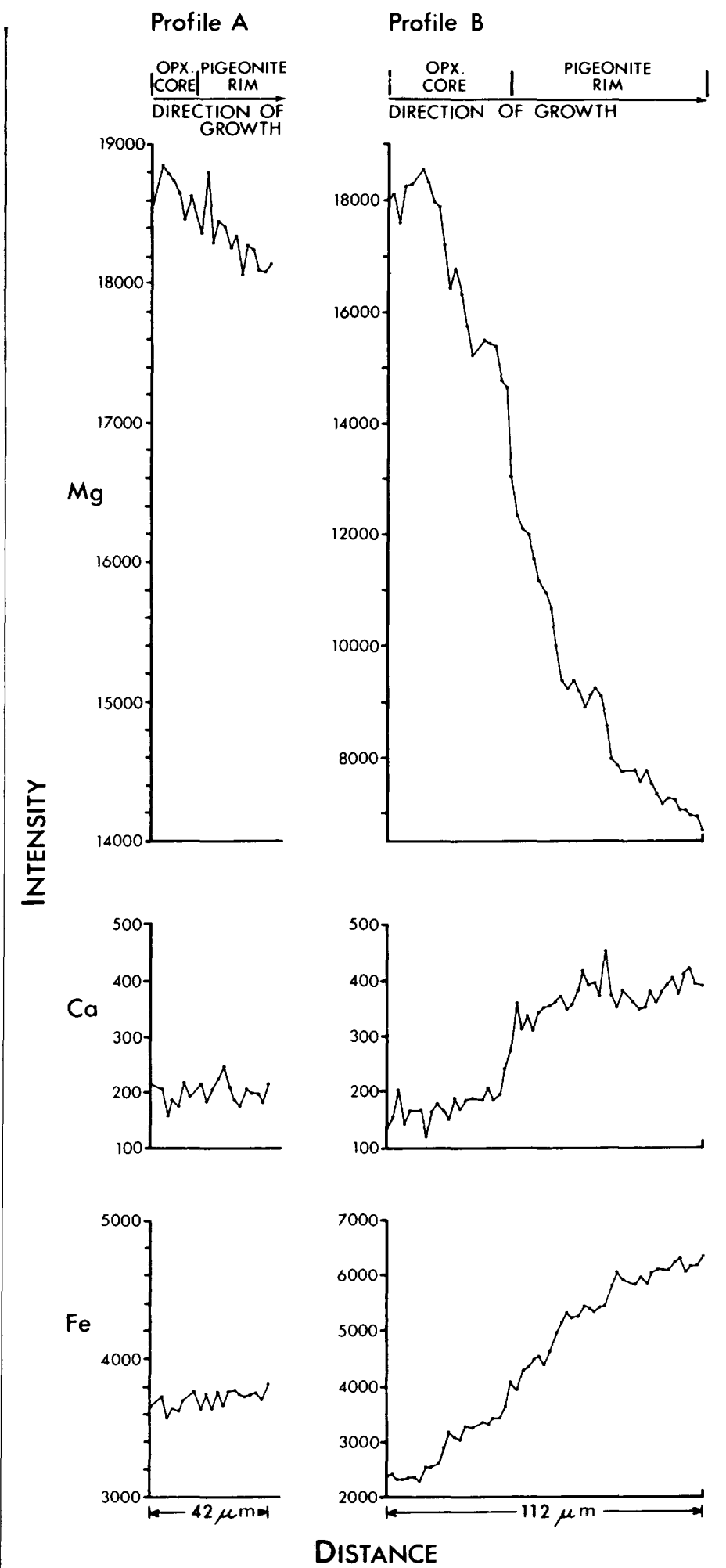

Figure 17.--Variations in $\mathrm{Mg}, \mathrm{Ca}$, and $\mathrm{Fe}$ contents along profiles across orthopyroxene-pigeonite contacts. Ordinate, abscissa, and designations of textural relations are as described in caption to figure 13. A is a profile across the contact in the composite grain illustrated in figure $5 A$. $B$ is a profile from center to edge of the composite grain illustrated in figure $5 B$. In profile $A$ there is virtually no compositional discontinuity at the contact, but in profile $B$ there is a strong discontinuity. 
eral strongly zoned with progressive iron enrichment toward their margins. The extent of zoning and the average $\mathrm{Fe} / \mathrm{Mg}$ ratio vary considerably from grain to grain. Variation of about 20 percent $F$ s content was the maximum observed in continuously zoned grains analyzed here, and none of the grains contains the complete range of $\mathrm{Fe} / \mathrm{Mg}$ ratios shown by all pigeonites as a group. As an illustration of typical zoning variation, a microprobe profile across the composite orthopyroxene-pigeonite-augite grain pictured in figure 7 is plotted on figure $12\left(A-A^{\prime}\right)$.

The coarse twinned pigeonite grains that are graphically intergrown with plagioclase are unusual in composition as well as texture. Points in such grains are $\mathrm{Wo}_{4} \mathrm{En}_{79} \mathrm{Fs}_{\mathrm{S}_{17}}$ to $\mathrm{Wo}_{6} \mathrm{En}_{69} \mathrm{Fs}_{25,}$, a compositional range nearly identical to that of the magnesian orthopyroxenes in the rock. In single grains of these pigeonites $\mathrm{Ca}$ contents are fairly constant, whereas $\mathrm{Fe}$ and $\mathrm{Mg}$ contents vary irregularly over the range given above; the grains increase abruptly in $\mathrm{Ca}$ and $\mathrm{Fe}$ at their extreme edges.

Ferropigeonites with Fs contents between 40 and 55 percent have highly variable Ca contents in comparison with pigeonites that have Fs less than 40 percent. This variability apparently indicates that many such grains consist of exsolution intergrowths of ferropigeonite and iron-rich augite, as demonstrated by data presented by Ridley and others (1972) and Takeda and Ridley (1972).

\section{AUGITE}

Compositional fields for the major textural types of augite are outlined on figure 12. Analyses reported by Ridley and others (1972) indicate that the field of overgrowth and interstitial augites extends to more iron-rich compositions than found in this study, as iron-rich as $\mathrm{Wo}_{32} \mathrm{En}_{2 \times} \mathrm{FS}_{40}$. The augites that form exsolution lamellae in orthopyroxene are too fine for accurate analysis, but the data suggest they are similar in composition to the augites that form exsolved blebs and prisms in this mineral.

\section{COMPOSITIONS OF PIGEONITE AND AUGITE AT THEIR CONTACTS}

In order to compare the compositions of coexisting pigeonite-augite pairs in 14310 with compositions of coexisting pyroxene pairs formed during equilibrium crystallization experiments, microprobe traverses were made across 24 pigeonite-augite contacts. Such comparisons yield information on whether or not the natural pyroxenes crystallized metastably or under equilibrium conditions. The Wo:En:Fs contents of the coexisting pyroxenes are plotted on figure 18.

\section{OTHER PYROXENES}

The compositions of small grains of highrefractive-index pyroxene in mesostasis are indi-

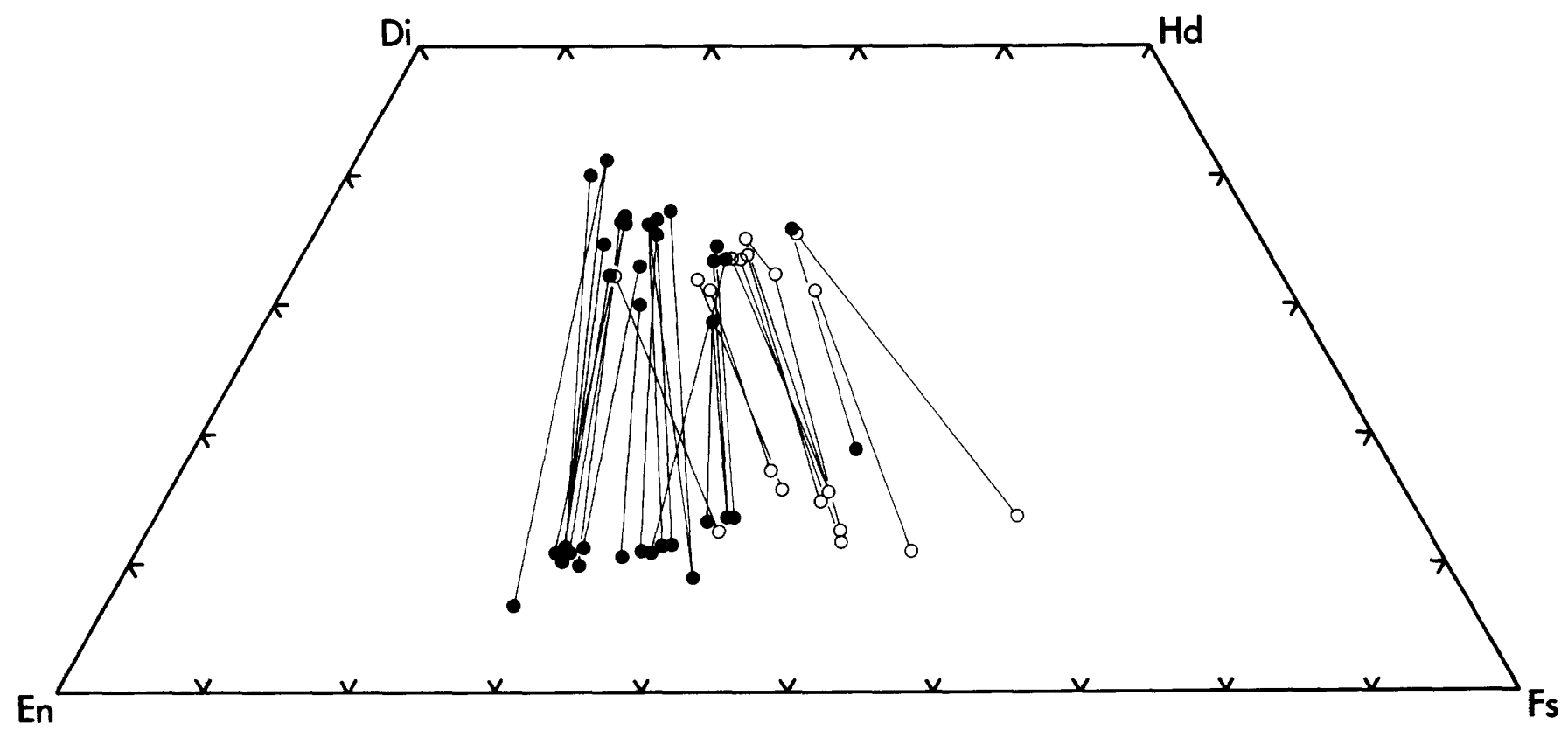

FIGURE 18.-Wo:En:Fs contents of coexisting augite and pigeonite. Solid circles are compositions of pyroxenes in contact where pigeonite is overgrown by augite; open circles are compositions of pyroxenes in contact where augite is overgrown by ferropigeonite. Solid lines connect compositions across the contacts, and the points are separated by no more than $6 \mu \mathrm{m}$. 
cated on figure 12. Most of these grains are very iron-rich ferropigeonites with $\mathrm{Fs}$ content ranging from 62 to 80 , but a few are more magnesian with Fs content as low as 40 .

Compositions of pyroxenes in fine-grained clots are plotted on figure 12 . These pyroxenes have $\mathrm{Fe} /$ $\mathrm{Mg}$ ratios about like average pigeonites elsewhere in the rock, but in $\mathrm{Ca}$ content they are intermediate between augite and pigeonite. Pyroxene that is within a fine-grained clot, but borders a reaction rim of whitlockite surrounding a Ni-Fe particle (fig. $2 D$ ), appears to be depleted in $\mathrm{Fe}$ and $\mathrm{Ca}$ relative to unreacted pyroxene within clots (see fig. 12).

The edges of four grains of pigeonite and one grain of augite immediately bordering vugs were analyzed. The pigeonites are $\mathrm{Wo}_{10-11} \mathrm{En}_{50-55} \mathrm{Fs}_{3,5-40}$ and the augite is $\mathrm{Wo}_{32} \mathrm{En}_{35} \mathrm{Fs}_{33}$.

Some intergranular grains of augite and ferropigeonite contain small patches of subcalcic augites whose compositions are fairly uniform and intermediate between pigeonite and augite. Analyses of points in several such patches of subcalcic augite, and the compositions of the adjacent augites and pigeonites, are plotted on figure 12.

\section{COMPOSITIONS OF INTERGROWN AND IMPINGING PLAGIOCLASE AND PYROXENE}

Intergrown and impinging grains of plagioclase and pyroxene were analyzed in order to obtain a rough calibration of compositional changes in the different pyroxenes relative to the crystallization history of the plagioclase. As would be expected, the more magnesian pyroxenes are intergrown with the more calcic plagioclase, and relatively iron-rich pyroxenes with relatively sodic plagioclase. Moreover, there are several consistent correlations of types of intergrowth textures with certain compositional ranges.

Most orthopyroxene grains that occur in intimate intergrowth with plagioclase are in the more magnesian part of the compositional range, $\mathrm{Wo}_{0_{4}} \mathrm{En}_{i 9} \mathrm{Fs}_{\mathrm{s}_{17}}$ to $\mathrm{Wo}_{4} \mathrm{En}_{72} \mathrm{Fs}_{\mathrm{S}_{4}}$. Coarse twinned pigeonites intergrown with plagioclase are of similar compositions. Cores of plagioclase grains included in, and centers of plagioclase grains graphically intergrown with, magnesian orthopyroxene range from $\mathrm{An}_{94}$ to $\mathrm{An}_{\mathrm{s} 2.4}$ and average $\mathrm{An}_{\mathrm{s} .2 .}$; centers of grains graphically intergrown with coarse twinned pigeonite range from $\mathrm{An}_{87.6}$ to $\mathrm{An}_{82.7}$. The few plagioclase grains intergrown with more iron-rich orthopyroxene tend to be more sodic, ranging from $\mathrm{An}_{88.5}$ to $\mathrm{An}_{80.1}$ and averaging $\mathrm{An}_{83.1}$. Within a few micrometers of contacts, the plagioclase grains are commonly slightly enriched in sodium and the pyroxene grains in iron.
The maximum sodium enrichment in plagioclase near contacts corresponds to an increase of about 10 percent in $\mathrm{Ab}$ content, and the maximum iron enrichment in pyroxene corresponds to an increase of about 5 percent in Fs content. Plagioclase bordering very iron rich orthopyroxene, $\mathrm{Wo}_{1,6} \mathrm{En}_{\overline{i, 1,1}} \mathrm{Fs}_{10 . .3}$, is more sodic, $\mathrm{Or}_{3, ;} \mathrm{Ab}_{1, i, j} \mathrm{An}_{\times 0,9}$. Plagioclase bordering a contact of augite and pigeonite $\left(\mathrm{Wo}_{3:} \mathrm{En}_{401} \mathrm{FS}_{2: 3}\right.$ rimming $\left.\mathrm{Wo}_{10} \mathrm{En}_{\overline{3}, 2} \mathrm{Fs}_{\mathrm{s}, 3 \times}\right)$ is $\mathrm{Or}_{3,2} \mathrm{Ab}_{1 \times, 4} \mathrm{An}_{i \mathrm{~s}_{4.4}}$. Plagioclases bordering more iron-rich augites are still more

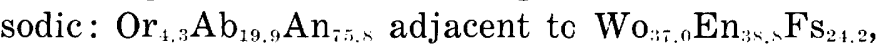
and $\mathrm{Or}_{\overline{i 1.1}} \mathrm{Ab}_{2 \tau .3} \mathrm{An}_{6 \pi, .6}$ adjacent to $\mathrm{Wo}_{3,4.0} \mathrm{En}_{3,3.5} \mathrm{Fs}_{32.5}$.

\section{OTHER SILICATE AND OXIDE PHASES}

Fayalite, potassium feldspar, and silica-rich glass are the only mesostasis phases analyzed in this study. The fayalite is $\mathrm{Fo}_{20-21}$; a complete analysis was given by Gancarz and others (1971). The potassium feldspar grains are all $\mathrm{Ba}$ rich and are somewhat variable in Na contents: In grains analyzed here, molecular percent of celsian ranges from 5.9 to 9.0, of albite from 6.4 to 10.4 , and of anorthite from 3.2 to 4.2 . Silica-rich glass is also rich in $\mathrm{K}$ but is poor in $\mathrm{Ba}$; Dence and Plant (1972), Kushiro and others (1972), Longhi and others (1972), and Roedder and Weiblen (1972) report that such glass contains 5-8 percent $\mathrm{K}_{2} \mathrm{O}$ and 75-77 percent $\mathrm{SiO}_{2}$. Other phases for which analyses have been reported are: ilmenite (Gancarz and others, 1971, and El Goresy and others, 1971) ; ulvöspinel (Haggerty, 1972, and E1 Goresy and others, 1972) ; baddeleyite (El Goresy and others, 1971) ; whitlockite (Brown and others, 1972, Gancarz and others, 1971, Griffin and others, 1972); tranquillityite (Brown and others, 1972, and El Goresy and others, 1972); a new Zr-rich mineral (Brown and others, 1972) ; and devitrified iron-rich glass (Roedder and Weiblen, 1972).

\section{Fe-Ni METAL AND SCHREIBERSITE}

Schreibersite and $\mathrm{Ni}-\mathrm{Fe}$ were analyzed to determine whether or not these phases show any compositional characteristics that are: (1) diagnostic of either meteoritic or indigenous origin; or (2) diagnostic of either crystallization from metal-rich melt or precipitation by reduction in silicate melt. Detailed studies were also made of compositions of coexisting metal and schreibersite in single particles, for under suitable conditions this mineral pair is an excellent recorder of subsolidus temperature history.

The analyses of $\mathrm{Ni}-\mathrm{Fe}$ reveal that there are two distinct compositional populations of metal in the rock: phosphorus-bearing and phosphorus-free. Mineral associations, and thus textures as well, are cor- 
related with this compositional grouping. Phosphorus-bearing metal grains consist of: all grains associated with schreibersite; a minor number of the small irregular particles that have no associated schreibersite; and about half the metal-bearing particles included in plagioclase. Phosphorus-free metal grains consist of : most of the irregular particles that have no associated schreibersite; about half the metal-bearing particles included in plagioclase; and most globules and small euhedra in troilite or mesostasis.

Compositions of the phosphorus-bearing metal grains cluster, with Ni ranging from 12 to 17.5 percent and Co from 0.6 to 1.2 percent (fig. 19A). The phosphorus-free grains, in contrast, vary widely in $\mathrm{Ni}$ and $\mathrm{Co}$, and contents of these elements are roughly linearly correlated (fig. 19B); variation is from near 0 to 42.4 percent $\mathrm{Ni}$ and 0 to 2.52 percent Co. (Error in the Co analyses may be relatively large, perhaps as great as \pm 0.1 percent absolute, and some of the scatter in Co values may be due to analytical error.) Other workers who analyzed $\mathrm{Ni}-\mathrm{Fe}$ in 14310 did not report $P$ values; their reported ranges for $\mathrm{Ni}$ and $\mathrm{Co}$ are within the ranges reported here (El Goresy and others, 1971; Gancarz and others, 1971; Ridley and others, 1972).

The schreibersites analyzed in this study have $\mathrm{Ni}$ contents from 11.2 to 29.8 percent and Co contents from 0.25 to 1.14 percent; within single grains these elements show large variations on a very fine scale produced by subsolidus equilibration. (El Goresy and others, 1971, reported an analysis of schreibersite with $\mathrm{Ni}$ and Co contents in the range found here; schreibersites analyzed by Axon and Goldstein, 1972, have slightly lower Ni but similar Co. No schreibersite with $\mathrm{Ni}<11$ percent was found in this study, but El Goresy and others, 1971, report finding pure $\mathrm{Fe}_{3} \mathrm{P}$ in their sample.)

\section{PHOSPHORUS-BEARING Ni-Pe AND SCHREIBERSITE}

Volumetrically, large composite particles like those illustrated in figure 9 contain most of the phosphorus-bearing $\mathrm{Ni}-\mathrm{Fe}$ and schreibersite in 14310. The $\gamma \mathrm{Ni}-\mathrm{Fe}^{1}$ that is the major constituent of these particles ranges in $\mathrm{Ni}$ from about 13 to 16 percent. Co contents are more variable, from 0.6 to 1.1 percent, and this element may be heterogeneously distributed even within single grains (uncertain because of possible analytical error). The $\gamma \mathrm{Ni}-\mathrm{Fe}$

\footnotetext{
${ }^{1}$ It is likely that this phase actually consists of a very fine exsolution intergrowth of $\alpha$ and $\gamma \mathrm{Ni}-\mathrm{Fe}$ that developed from $\gamma \mathrm{Ni}-\mathrm{Fe}$ during low temperature subsolidus equilibration; as the original phase was $\gamma \mathrm{Ni}-\mathrm{Fe}$ and the exsolution is too fine to resolve with methods used here, the designation $\gamma$ will be used in this paper for all $\mathrm{Ni}-\mathrm{Fe}$ of suitable composition.
}

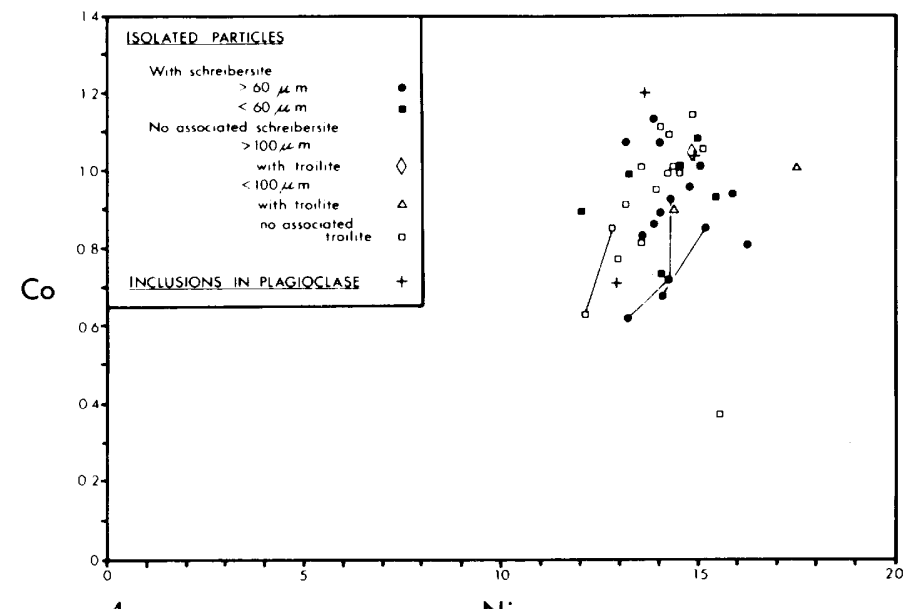

$\boldsymbol{A}$

$\mathrm{Ni}$

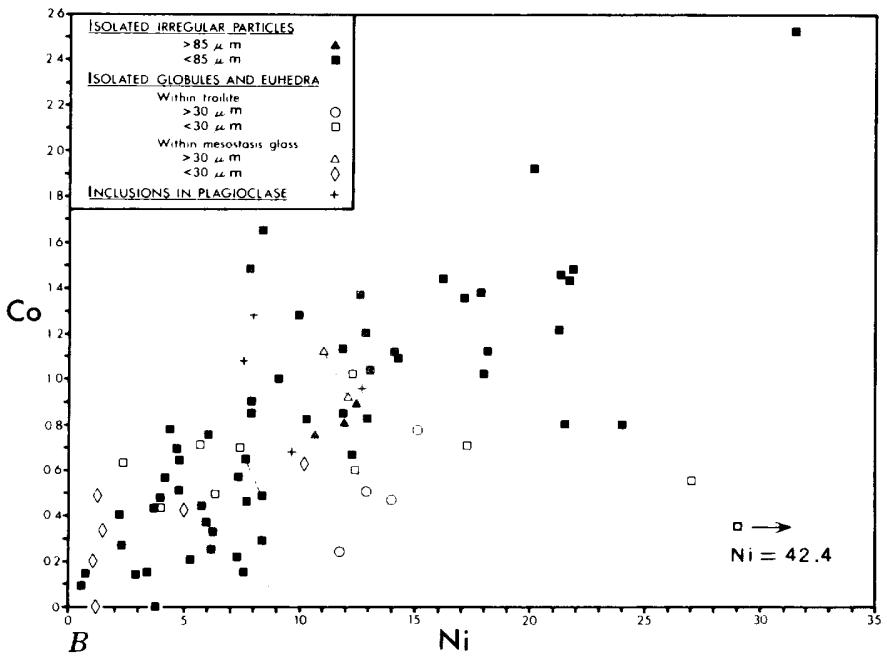

FiguRE 19.-Ni and Co contents, in weight percent, of grains of phosphorus-bearing $(A)$ and phosphorus-free $(B) \mathrm{Ni}-$ Fe. Solid lines connect compositions of points in the same grain. Particles designated as "isolated" are those not included in plagioclase or pyroxene.

grains commonly have rims a few micrometers thick, formed during subsolidus equilibration, of $\alpha \mathrm{Ni}-\mathrm{Fe}$ that contains about 7 percent $\mathrm{Ni}$. $\mathrm{Ni}$ content in schreibersite in any given composite particle varies widely; a common range observed is from about 2 percent less than, to about 10 percent greater than the $\mathrm{Ni}$ content in associated $\gamma \mathrm{Ni}-\mathrm{Fe}$. However, Co content in schreibersite is always less than the Co content in associated $\alpha$ or $\gamma \mathrm{Ni}-\mathrm{Fe}$. To illustrate these compositional variations, the compositional data for the two globules pictured in figure 9 are presented in detail below.

The compositional data for $\mathrm{Ni}-\mathrm{Fe}$ and schreibersite in the particle illustrated in figure $9 \mathrm{~A}$ are plotted on figures 20 (profile A) and $21 A$. As is evident in figure 20, the large grain of $\gamma \mathrm{Ni}-\mathrm{Fe}$ that forms the bulk of the particle is zoned: Ni content 


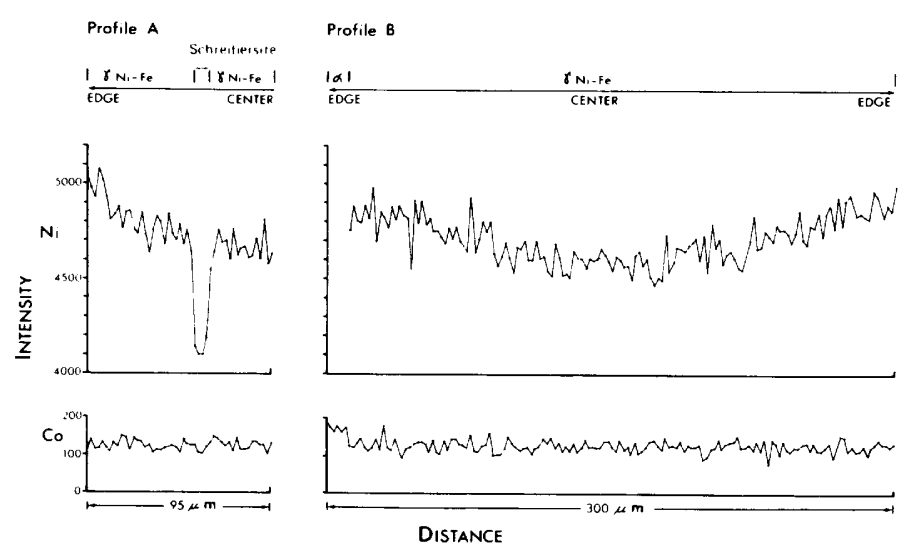

Figure 20.- Variations in $\mathrm{Ni}$ and Co contents along profiles across large $\mathrm{Fe}-\mathrm{Ni}-\mathrm{P}-\mathrm{S}$ globules. Ordinate, abscissa, and designations of textural relations are the same as described for figure 13. Profiles A and B correspond to profiles indicated on figure 9 . On profile $\mathrm{B}$, the counts for $\mathrm{Ni}$ in the a $\mathrm{Ni}-\mathrm{Fe}$ phase are not plotted because they are below the indicated scale.
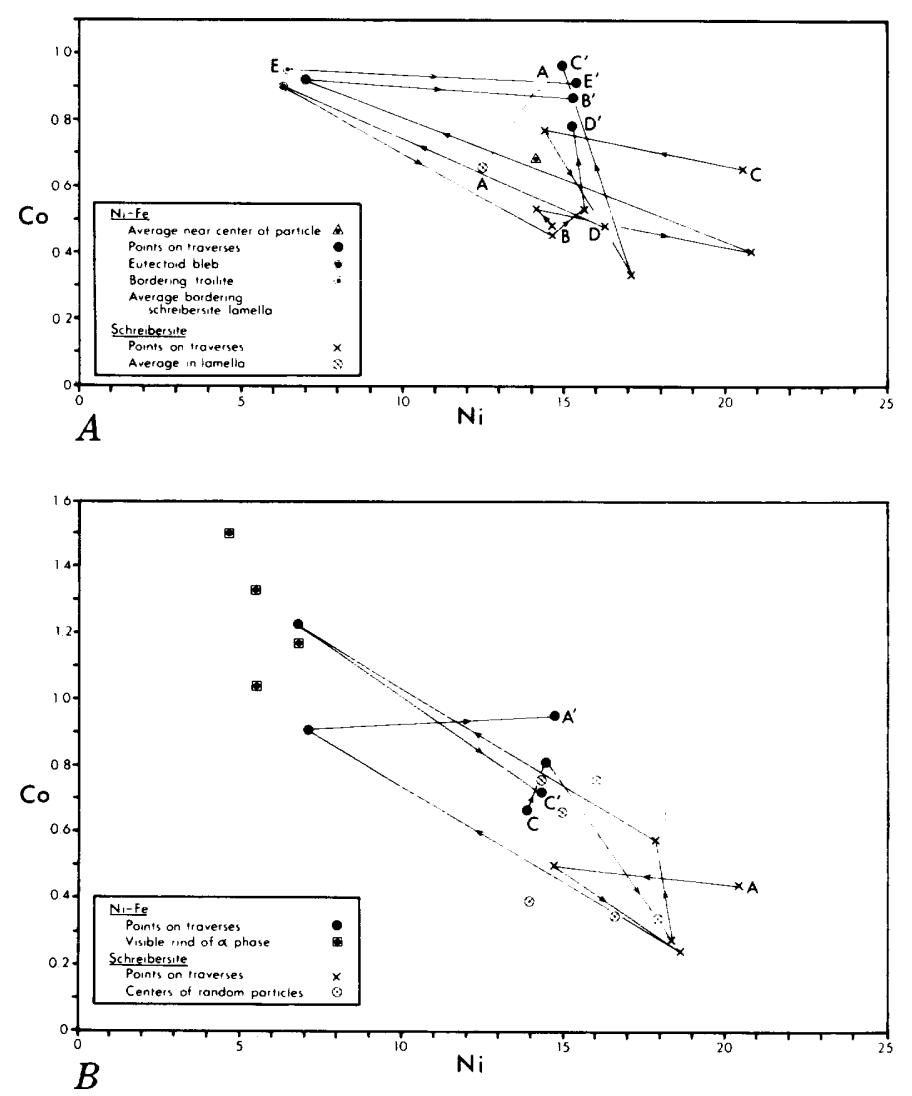

FIGURE 21.- $\mathrm{Ni}$ and $\mathrm{Co}$ contents (in weight percent) of $a$ $\mathrm{Ni}-\mathrm{Fe}, \gamma \mathrm{Ni}-\mathrm{Fe}$, and schreibersite in large $\mathrm{Fe}-\mathrm{Ni}-\mathrm{P}-\mathrm{S}$ globules. Solid lines connect consecutive (but not always adjacent) points on traverses across phases at edges of globules; arrows indicate traverse direction and point from the extreme edge toward the interior of the particle. $A$, Points in the particle illustrated in figure $9 A$. Dashed line connects the average composition of a schreibersite lamella on traverse $A-A$ with the composition of $\gamma \mathrm{Ni}-\mathrm{Fe}$ progressively increases from about 14.1 percent at its center to about 15.2 percent at its edge. The schreibersite lamella analyzed is about 1.75 percent lower in $\mathrm{Ni}$ than bordering $\gamma \mathrm{Ni}-\mathrm{Fe}(A-A$, fig. $21 A$ ). Traverses $B-B^{\prime}$ and $C-C^{\prime}$ plotted on figure $21 A$ show clearly that schreibersite immediately adjacent to $\alpha \mathrm{Ni}-\mathrm{Fe}$ is enriched in $\mathrm{Ni}$ and depleted in Co relative to schreibersite at the center of the marginal grains of this mineral.

The compositional data for phases in the globule illustrated in figure $9 B$ are shown on figures 20 (profile $\mathrm{B}$ ) and $21 B$. The $\gamma \mathrm{Ni}-\mathrm{Fe}$ in this globule shows zoning similar to that in the globule described above, with $\mathrm{Ni}$ increasing progressively toward the edges of the grain. Ni enrichment of schreibersite immediately adjacent to $\alpha \mathrm{Ni}-\mathrm{Fe}$ is evident in the two traverses plotted on figure $21 B$. Unlike in the globule pictured in figure $9 \mathrm{~A}$, the $\alpha \mathrm{Ni}-\mathrm{Fe}$ analyzed here is appreciably enriched in Co relative to $\gamma \mathrm{Ni}-\mathrm{Fe}$ as well as to schreibersite. Inhomogeneities in Co distribution are suggested by the data, but their magnitude is close to the estimated uncertainty in the analyses.

$\mathrm{Ni}$ and $\mathrm{Co}$ contents in all analyzed metal and schreibersite grains included in plagioclase are plotted on figure 22. The compositional variations in the large schreibersite-bearing inclusion illustrated in figure 10 (traverse $A-A^{\prime}$ on fig. 22) are like those shown by the large globules pictured in figure 9

immediately bordering it. Traverses $B-B^{\prime}$ and $C-C^{\prime}$ show the compositions of, consecutively: schreibersite at the extreme edge of the particle; schreibersite at the center of a marginal grain; schreibersite immediately bordering $a \mathrm{Ni}-\mathrm{Fe} ; \boldsymbol{a} \mathrm{Ni}-\mathrm{Fe}$ (resolvable and plotted only in $B-B^{\prime}$ ); and the edge of the $\gamma \mathrm{Ni}-\mathrm{Fe}$ grain bordering $a \mathrm{Ni}-\mathrm{Fe}$. Points on the $D-D^{\prime}$ traverse show the compositions of, consecutively: schreibersite at the extreme edge of the particle; a small bleb of a Ni-Fe with eutectoid texture in marginal schreibersite; schreibersite (two points) bordering the central $\gamma \mathrm{Ni}-\mathrm{Fe}$ grain; and the edge of the $\gamma \mathrm{Ni}-\mathrm{Fe}$ grain. The $E-E^{\prime}$ traverse shows the composition of a Ni-Fe in contact with troilite and the composition of $\gamma \mathrm{Ni}-\mathrm{Fe}$ bordering the $a$ phase. $B$, Points in the particle illustrated in figure $9 B$. Traverse $A-A^{\prime}$ is similar to the traverses $B-B^{\prime}$ and $C-C^{\prime}$ described in $A$ above. The $C-C^{\prime \prime}$ traverse shows compositions of, consecutively: a small bleb of $\gamma \mathrm{Ni}-\mathrm{Fe}$ (two points) enclosed in a patch of schreibersite at the margin of the particle; schreibersite (two points) forming a narrow band that intervenes between the $\mathrm{Ni}-\mathrm{Fe}$ bleb and the central $\mathrm{Ni}-\mathrm{Fe}$ grain; a Ni-Fe forming a thin rind between schreibersite and $\gamma \mathrm{Ni}-\mathrm{Fe}$; and $\gamma \mathrm{Ni}-\mathrm{Fe}$ at the edge of the central metal grain. Also plotted are compositions of the centers of several randomly chosen grains of schreibersite along the margins of the particle, and compasitions of a $\mathrm{Ni}-\mathrm{Fe}$ at points where this phase forms a rind thick enough to be optically discernible. 


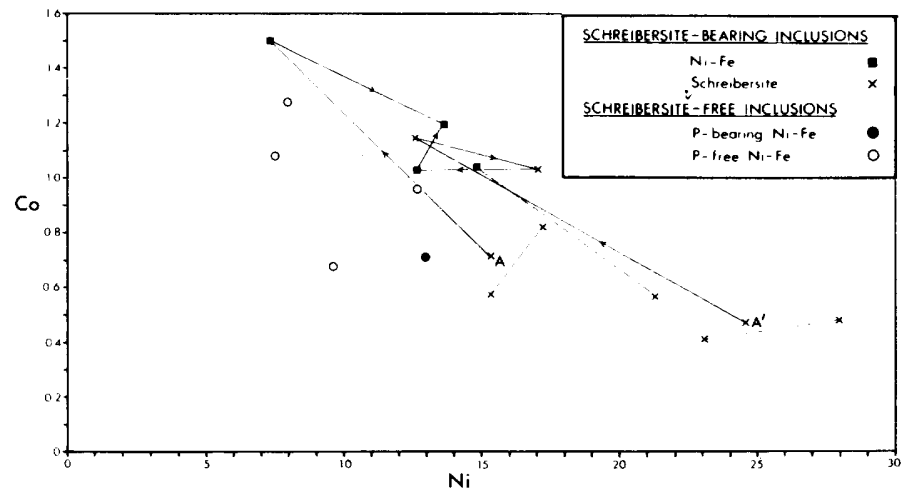

Figure 22.-Ni and Co contents (in weight percent) of $a$ $\mathrm{Ni}-\mathrm{Fe}, \gamma \mathrm{Ni}-\mathrm{Fe}$, and schreibersite included in plagioclase. Data for both phosphorus-bearing and phosphorus-free particles are plotted. Where two points in single inclusions were analyzed, dashed lines connect compositions of these points. Phase assemblages are: $\gamma \mathrm{Ni}-\mathrm{Fe}$; schreibersite; $\gamma$ $\mathrm{Ni}-\mathrm{Fe}+$ troilite; schreibersite + troilite; $\gamma \mathrm{Ni}-\mathrm{Fe}+$ schreibersite + troilite; and $a \mathrm{Ni}-\mathrm{Fe}+\gamma \mathrm{Ni}-\mathrm{Fe}+$ schreibersite. The inclusion containing the last of these assemblages is the one pictured in figure 10 . Traverse $A-A^{\prime}$ shows the compositions of points in the inclusion pictured in figure 10; solid lines connect consecutive points on this traverse, and arrows indicate the direction of the center of the inclusion.

(traverses $B-B^{\prime}$ and $C-C^{\prime}$ on fig. $21 A$, traverse $A-A^{\prime}$ on fig. $21 B$ ).

\section{PHOSPHORUS-FREE Ni_Fe}

Large isolated irregular particles of phosphorusfree $\mathrm{Ni}-\mathrm{Fe}$ all have fairly similar compositions, $\mathrm{Ni}$ ranging from 10 to 13 percent and Co from 0.75 to 0.9 percent (fig. 19B); unlike the phosphorusbearing particles, they are unzoned and are either homogeneous or their compositions vary irregularly. Small isolated irregular particles have compositions that cover the entire range plotted on figure $19 B$. Small particles with spherical or euhedral outlines show some consistent correlations of composition with occurrence. Such particles in mesostasis glass have less than 12 percent $\mathrm{Ni}$ and less than 1.1 percent $\mathrm{Co}$, and content of these elements seems roughly proportional to size. Globules of metal in troilite show a very wide range of $\mathrm{Ni}$ contents ( 2 to 42.4 percent) but much more restricted Co (nearly all are in the range 0.24 to 0.77 percent). (El Goresy and others, 1971, also pointed out that the grains they analyzed with highest $\mathrm{Ni}$ contents tend to be associated with troilite.)

\section{CRYSTALLIZATION AND COOLING HISTORY}

The data presented in this paper indicate that feldspathic basalt 14310 crystallized from a melt of the same, or nearly the same, bulk composition as the rock now has. Globules of Fe-Ni-P-S melt that were immiscible in the silicate melt, and possibly also particles of crystalline $\mathrm{Ni}-\mathrm{Fe}$, were present in the magma very early in its crystallization sequence. Evidence for this latter inference is that: (1) plagioclase typical of the earliest part of the silicate crystallization sequence, $\mathrm{An}_{94}$, envelops metal particles; and (2) some Fe-Ni-P-S particles are as much as $300 \mu \mathrm{m}$ across and their outlines are not greatly interfered with by adjacent plagioclase grains. As the silicate and metal-rich melts crystallized as separate systems, the sequence of events in each is described separately below.

\section{SILICATE MELT}

The first crystals of a silicate mineral present in the 14310 magma were of plagioclase, $\mathrm{An}_{94-95}$. These crystals formed in the melt and were not xenocrysts, for their cores preserve traces of euhedral outlines and their zoning patterns and textures show no evidence of an episode of reheating. (The irregular zoning cited by Ridley and others, 1972, as evidence for broken crystals probably resulted from growth of impinging grains during the middle part of the crystallization sequence.) Grain-size distribution is roughly seriate, and few, if any, true phenocrysts are present. Cores of the larger grains might represent early formed cumulus crystals, but these make up only 3-4 percent by volume of the total rock (results of point count on 14310,9). The texture (seriate grain sizes, random orientation of laths) indicates that virtually all of the rock must have crystallized in situ.

The overall pattern of compositional change in plagioclase is one of orderly normal progressive zoning with superimposed minor reversals and oscillations. Cores of the large plagioclase laths analyzed in this study are outlined by sodium-depleted zones that represent an increase in anorthite content of about 2 percent. This zoning reversal may be a reflection of melt-wide loss of alkalis by volatilization early in the crystallization sequence. The grains show no evidence of consistent melt-wide reverse zoning formed later in the sequence. Minor oscillations and reversals in composition occur, but these vary from grain to grain and probably reflect local changes in growth environment of single crystals. Compositions and zoning are similar in large and intermediate-size laths, and most plagioclase adjacent to mesostasis glass-whether small laths in interstices or edges of larger laths-is relatively sodic, $\mathrm{An}_{62-i s .}$. The simplest explanation for these observations is that abundant nuclei of calcic plagioclase formed early in the crystallization sequence 
and cores of intermediate-size laths crystallized simultaneously with cores and intermediate zones of larger laths (also suggested by Ridley and others, 1972, and Longhi and others, 1972). The evidence presented here indicates that, although there may have been minor volatilization of alkalis shortly after crystallization began, profound alkali volatilization (proposed by Brown and Peckett, 1971) did not occur at any point in the crystallization sequence.

In crystallization experiments by Ford and others (1972), chrome spinel was the next phase to precipitate from the melt. There is no trace of this mineral in the natural rock. If chrome spinel formed in the natural crystallization sequence, it was later completely resorbed. Moreover, the crystallization experiments (Ford and others, 1972; Kushiro and others, 1972; Green and others, 1972; Walker and others, 1972) show olivine as the first, or one of the first, of the mafic silicates to form. In the experiments the olivine reacted with melt and was resorbed on precipitation of pigeonite. No evidence of olivine crystallization is preserved in the natural rock, but if only a small proportion of this mineral formed it could have been completely resorbed without leaving a trace.

Orthopyroxene was the second silicate mineral to precipitate from the melt for which evidence is recorded in the natural rock. None of the crystals of this mineral are xenocrysts. Hollister and others (1972) cite presence of reverse zoning as evidence that cores of some grains are exotic, but the results of this study indicate that the reverse zoning formed during in situ magmatic crystallization. The evidence is as follows: (1) some reverse-zoned grains are graphically intergrown with plagioclase and must have grown in situ; and (2) in many or most grains with reverse zoning, such zoning is not a single simple reversal but is associated with complex oscillatory zoning related to preserved traces of euhedral growth surfaces. The reverse and associated oscillatory zoning in pyroxene are probably the results of fluctuations in conditions such as oxygen and (or) sulfur fugacity during crystallization.

Most orthopyroxene probably crystallized from the melt as orthopyroxene. The cores of most composite orthopyroxene-pigeonite grains did not form by inversion from enclosing pigeonite, for $c$ axes and $\{010\}$ planes of the two minerals do not generally coincide. The preferential developments of $\{100\}$ relative to $\{210\}$ and $\{010\}$ crystal faces, where traces of such planes are preserved, suggests that the crystals grew from the melt as orthopyroxene and not pigeonite. A small proportion of the orthopyroxene did form by inversion of calcium-poor, magne- sium-rich pigeonite, but textures of such grains generally indicate their origin.

The magnesian orthopyroxene grains that show complex combinations of reverse, oscillatory, and normal progressive zoning, and in some cases small iron-rich nuclei, may have been among the first crystallized. If so, precise composition of the earliest orthopyroxene is difficult to determine. Composition of plagioclase crystallizing from the melt when such orthopyroxene formed appears to have been about $\mathrm{An}_{88-89}$ (estimated from analyses of plagioclase included by or intergrown with orthopyroxene). This estimate is supported by the results of 1-atmosphere experimental crystallization studies by Ford and others (1972), in which $\mathrm{An}_{88}$ is the plagioclase precipitating at temperatures slightly above first precipitation of pyroxene.

Rock texture suggests that during coprecipitation of orthopyroxene and plagioclase local concentrations of volatiles developed in the melt. (Unfortunately, compositions of these volatile constituents cannot be specified on the basis of the data now available.) At the sites of these concentrations, graphic intergrowths developed relatively coarse grain size, and later in the crystallization sequence open vugs formed. Variations in volatiles likely produced the reverse and oscillatory zoning observed in pyroxene formed during this period, and the abundant minute glass inclusions in some grains may represent trapped droplets of a volatile-rich phase.

The precise sequence of events during the period when pigeonites first precipitated appears to have varied from place to place in the rock, probably reflecting local variations in compositions and conditions in the crystallizing melt. The observed relationships could be interpreted in several different ways, but one of the more likely of these interpretations follows. Temperature and bulk composition of the melt were such that crystallization of the early pyroxenes occurred very close to the orthopyroxenepigeonite transition curve. Local variations in volatile and minor-element contents, and possibly also in temperature, produced conditions such that orthopyroxene and pigeonite were alternately stable at the same point in the melt, or simultaneously stable at different points. Rims of magnesium-rich, calcium-poor pigeonite that overgrew orthopyroxene of identical composition formed as a result of such conditions. Furthermore, it is likely that the coarse polysynthetically twinned grains of magnesium-rich, calcium-poor pigeonite formed by inversion of pyroxene that initially crystallized as orthopyroxene. The textures of some of these grains definitely suggest a pigeonite-orthopyroxene inversion relation- 
ship (fig. 8), and the X-ray patterns of the pigeonites indicate inversion from orthopyroxene (Malcolm Ross, oral commun., 1972). The compositions of the orthopyroxenes and pigeonites are in many cases identical, however, whereas the compositions of the two pyroxenes should differ by about 4 percent in Wo content if the transition took place under equilibrium conditions (Malcolm Ross, oral commun., 1972). Thus it is likely that the inversion was not an equilibrium process. Cores of some of the magnesium-rich pigeonites subsequently inverted to orthopyroxene with little or no exsolution of augite. Orthopyroxene that contains abundant exsolved lamellae of augite probably also initially crystallized as pigeonite, for the primary pyroxene in such grains appears to have had a calcium content appropriate for pigeonite (fig. 14). This pigeonite inverted to orthopyroxene and then exsolved augite, as is indicated by the crystallographic orientation of the lamellae (Huebner and Ross, 1972). At some point in the crystallization sequence, however, orthopyroxene became generally unstable and began to be resorbed, and pigeonite became the stable pyroxene phase precipitating throughout most of the melt. Most orthopyroxene grains in the rock appear to have continued precipitation until this point in the crystallization sequence was reached. Their margins have compositions of $\mathrm{Fs}>\mathbf{2 5}$ and they were overgrown by pigeonite appreciably enriched in $\mathrm{Ca}$ and (or) $\mathrm{Fe}$ (see fig. 16). Comparison with phase relations experimentally determined by Huebner and Ross (1972) suggests that this type of pigeonite crystallization was an equilibrium process. Locally, however, crystallization of orthopyroxenes progressively enriched in iron continued well beyond the point at which this pyroxene had ceased to form in the rest of the melt, and crystallization of the most iron-rich orthopyroxenes overlapped with crystallization of ilmenite.

The above sequence of events in pyroxene crystallization is supported by data on compositions of coexisting plagioclase and pyroxene. Magnesian orthopyroxene $(\mathrm{Fs}<25)$ is graphically intergrown with plagioclase averaging $\mathrm{An}_{8 \tau}$ and iron-rich orthopyroxene $(\mathrm{Fs}>25)$ with plagioclase averaging $\mathrm{An}_{83}$. Analyses of pyroxenes and plagioclases where they impinge upon each other show that orthopyroxenes and coarse twinned pigeonites of identical compositions, about $\mathrm{Fs}_{21}$, border plagioclases also of identical compositions, about $\mathrm{An}_{\mathrm{s} 5}$. Orthopyroxene extremely enriched in iron, $\mathrm{Fs}_{40}$, impinges on more sodic plagioclase, $\mathrm{An}_{\mathrm{s} 1}$.

Shortly after the initiation of pigeonite crystallization throughout the melt and resorption of ortho- pyroxene, augite also began to precipitate. Both augite and pigeonite continued to crystallize simultaneously, with local compositional variations in the melt determining which pyroxene was precipitating at any given place (similar to crystallization patterns in composite pigeonite-augite phenocrysts in Apollo 12 basalts described by Boyd and Smith, 1971). The pattern of crystallization is that which would be predicted for stable cotectic crystallization of augite and pigeonite (Ridley and others, 1972; experimental phase data reported by Ross and others, 1973). Plagioclase that formed during this period of cotectic crystallization is more sodic than that bordering the earlier formed orthopyroxene or magnesian pigeonite. $\mathrm{An}_{78}$ borders an augite-pigeonite contact where the pyroxenes have $\mathrm{Fe} / \mathrm{Mg}$ ratios about in the middle of the compositional range shown on figure 18, and still more sodic plagioclase, $\mathrm{An}_{68}$, is in contact with more iron-rich augite.

During coprecipitation of augite, pigeonite, and plagioclase, vugs were forming in areas of volatile concentrations. Ilmenite probably began precipitating during this same period, for most ilmenite is enveloped by ferropigeonite, augite, or mesostasis, and none was observed in orthopyroxene (except in anomalously iron-rich grains) or in magnesian pigeonite.

When the magma had almost entirely crystallized, augite precipitation ceased and ferropigeonite was the only pyroxene to continue crystallizing. Just prior to and just after cessation of augite crystallization, subcalcic augites with compositions intermediate between augite and pigeonite precipitated locally. These subcalcic augites and calcium-rich ferropigeonites that now consist of exsolution intergrowths of ferropigeonite and augite likely crystallized as metastable pyroxenes (compare fig. 12 in this paper with fig. 10 in Ross and others, 1973).

Final events in crystallization of the silicate melt were: precipitation in interstices of very iron-rich ferropigeonite, fayalite, barium-rich potassium feldspar, tranquillityite, and baddeleyite; and quenching of silica-rich and iron-rich immiscible melts to form glasses. Plagioclase bordering these late-stage mesostasis materials is the most sodic in the rock, as sodic as $\mathrm{An}_{62}$.

Fine-grained clots.-Origin of the fine-grained clots is a problem of special significance to the question of origin of the 14310 melt. Previous investigators have interpreted these clots as possible cognate inclusions (LSPET, 1971; Gancarz and others, 1971; Walter and others, 1972) or as possible products of in situ crystallization (Brown and Peckett, 1971; Ridley and others, 1972). Textural evidence strongly 
favors the latter interpretation: Textures of the clots grade into textures typical of the rest of the rock, and the clots are commonly surrounded by zones enriched in mesostasis. Compositions of minerals in the clots, however, do not follow the same consistent patterns shown by coexisting minerals elsewhere in the rock. The plagioclases are of the very calcic compositions typical of the early part of the crystallization sequence, but the pyroxenes have $\mathrm{Fe} / \mathrm{Mg}$ ratios characteristic of pyroxenes crystallizing during coprecipitation of augite, pigeonite, and plagioclase. Furthermore, Ca contents of the pyroxenes are intermediate between those of augite and pigeonite and suggest that they may have crystallized metastably.

\section{Fe-Ni-P-S MELTS AND PARTICLES}

While the silicate melt was crystallizing, the globules of $\mathrm{Fe}-\mathrm{Ni}-\mathrm{P}-\mathrm{S}$ melt it contained were precipitating $\mathrm{Ni}-\mathrm{Fe}$ metal, schreibersite, and troilite. In one of the large $\mathrm{Fe}-\mathrm{Ni}-\mathrm{P}-\mathrm{S}$ melt globules described in detail here (illustrated in fig. $9 A$ ), the textural and compositional variations are a particularly good illustration of its crystallization history. In this globule the first phase to form was $\gamma \mathrm{Ni}-\mathrm{Fe}$, which precipitated as a single grain. The grain is progressively enriched in Ni toward its margins, a zoning pattern far more likely to be developed in a grain crystallizing from a metal-rich melt than in a crystal precipitated directly by reduction in a silicate melt. When crystallization was nearly complete, schreibersite, and then troilite, began to precipitate along with the metal from melt concentrated at the edges of the globule. Crystallization of schreibersite and troilite did not begin until surrounding silicate melt was almost entirely solidified, for these two minerals are molded on adjacent grains of silicate minerals. In the end stages of crystallization, phosphorus derived from the metal-rich particle combined with calcium from the surrounding silicate melt to precipitate apatite and whitlockite grains in mesostasis bordering the globule.

In other large particles less rich in total phosphorus there appears to have been little or no primary precipitation of schreibersite, and all grains of this mineral apparently exsolved from coexisting metal. In these particles, texture alone does not indicate whether or not the metal crystallized from metal-rich melt or precipitated by reduction of silicate melt. Only one such particle has been studied in detail (fig. $9 B$ ) ; here the presence of $\mathrm{Ni}$ enrichment toward margins of the metal grain suggests growth in metal-rich melt.

In contrast, it is likely that most of the phosphorus-free $\mathrm{Ni}-\mathrm{Fe}$ particles precipitated directly by reduction of the silicate melt during the crystallization sequence. Characteristics consistent with this interpretation are: (1) The particles fill irregular interstices, most quite small; and (2) zoning is generally absent and the grains are either homogeneous or their compositions vary irregularly. Particles that contain appreciable proportions of both $\mathrm{Ni}-\mathrm{Fe}$ and troilite probably crystallized from late-stage $\mathrm{Fe}-$ $\mathrm{Ni}-\mathrm{S}$ melts immiscible in the silicate melt, for their textures are like those of the Apollo 11 metal + troilite particles that formed from such immiscible melts (Skinner, 1970).

\section{SUBSOLIDUS EFFECTS}

Changes in texture and composition of phases continued to take place during cooling below the solidus. Such changes were substantial in coexisting $\mathrm{Ni}-\mathrm{Fe}$ and schreibersite and their results are obvious in the petrographic and microprobe data. Subsolidus equilibration was also extensive in the pyroxenes, producing exsolution and cation ordering (Gibb and others, 1972; Finger and others, 1972; Schürmann and Hafner, 1972; Ghose and others, 1972; Takeda and Ridley, 1972), but these effects are for the most part not on a scale easily investigated by the methods used here.

The effects of subsolidus equilibration in coexisting metal and schreibersite are those that would be predicted from experimental phase relations (Doan and Goldstein, 1969, 1970). In particles relatively rich in phosphorus, such as the one illustrated in figure $9 A, \gamma \mathrm{Ni}-\mathrm{Fe}$ began to exsolve lamellae and marginal grains of schreibersite immediately after crystallization ceased. In other particles with less phosphorus, such as the one shown in figure $9 B$, schreibersite may not have begun to exsolve until the temperature had dropped appreciably below the solidus. Schreibersite that formed at or close to the solidus was slightly poorer in $\mathrm{Ni}$ than coexisting $\gamma$ $\mathrm{Ni}-\mathrm{Fe}$. As temperature dropped and more schreibersite formed, this mineral was progressively enriched in $\mathrm{Ni}$ and depleted in Co relative to adjacent metal. As temperature dropped still further, thin rinds of $\alpha \mathrm{Ni}-\mathrm{Fe}$, much depleted in $\mathrm{Ni}$ relative to adjacent $\gamma$ $\mathrm{Ni}-\mathrm{Fe}$ and schreibersite, formed at interfaces. Within a few micrometers of contacts with metal, schreibersite continued to be progressively enriched in $\mathrm{Ni}$ 
and depleted in Co until equilibration ceased.

\section{CRYSTALLIZATION CONDITIONS}

\section{PRESSURE}

Crystallization of the 14310 melt probably took place entirely at or very near the lunar surface. The large metal particles that were present early in the course of crystallization were not removed by settling, and the first-formed pyroxenes are graphically intergrown with plagioclase, indicating crystallization of the bulk of the rock at a single site. The fine grain size of the rock and the presence of vugs indicate that this site was near or at the lunar surface. Cores within large plagioclase grains $(<3-4$ percent by volume of total rock) are the only fraction that could conceivably have formed prior to surface crystallization.

\section{TEMPERATURE}

As basalt 14310 represents a melt crystallized at low pressures, the approximate temperature history of crystallization can be derived from the results of experimental crystallization studies at 1 atmosphere. Liquidus temperature for the silicate minerals is about $1310^{\circ}-1320^{\circ} \mathrm{C}$ (Ford and others, 1972 ; Walker and others, 1972; Green and others, 1972), but liquidus temperatures for the immiscible $\mathrm{Fe}-\mathrm{Ni}-\mathrm{P}-\mathrm{S}$ melts may have been appreciably higher. The approximate bulk composition of the $\mathrm{Fe}-\mathrm{Ni}-\mathrm{P}-\mathrm{S}$ globule pictured in figure $9 \mathrm{~A}$ is, in weight percent, 81.2 $\mathrm{Fe}, 14.0 \mathrm{Ni}, 1.1 \mathrm{Co}, 2.3 \mathrm{P}$, and $1.4 \mathrm{~S}$ (derived from averaged microprobe analyses of phases and point counts of phase proportions converted to volume percent and corrected for the effects of sphericity). No experimental data are available for the liquidus temperature of such a mix, but estimates based on data for the binary systems $\mathrm{Fe}-\mathrm{Ni}, \mathrm{Fe}-\mathrm{S}$, and $\mathrm{Fe}-\mathrm{P}$ (Hansen and Anderko, 1958) suggest a liquidus temperature around $1375^{\circ} \mathrm{C}$. If, however, these metalrich melts contained appreciable initial $\mathrm{P}$ or $\mathrm{S}$, or both, that was lost during crystallization, their liquidus temperatures could have initially been much lower. The presence of concentrations of phosphate minerals bordering the particles indicates that initial $\mathrm{P}$ content was indeed greater than at present, but the magnitude of $\mathrm{P}$ loss is nearly impossible to estimate. In order to lower the liquidus temperature of the globule pictured in figure $9 \mathrm{~A}$ to near that of the silicate minerals, the initial content of $\mathrm{P}+\mathrm{S}$ would have to have been about double that now present. Most other composite Fe-Ni-P-S particles, such as the one pictured in figure $9 B$, have still less $\mathrm{S}$ and $P$ and would have required even greater losses of these constituents to lower their liquidus temperatures to that of the silicate melt. Rock texture yields no definitive evidence on whether or not such large proportional losses of $\mathrm{P}$ and (or) $\mathrm{S}$ are reasonable.

The natural crystallization sequence at the point of entry of the mafic silicates does not appear to have been reproduced experimentally by any group of investigators. In experiments reported by Ford and others (1972) and Green and others (1972), olivine precipitated at about $1230^{\circ} \mathrm{C}$ and no orthopyroxene formed. In experiments by Walker and others (1972), orthopyroxene was the first major mafic mineral to crystallize, but during their experiments it appears that there was significant loss of $\mathrm{FeO}$ from the silicate melt. However, all groups found that the second major mafic mineral was pigeonite and that this pyroxene formed by reaction of the first major mafic silicate with melt between $1200^{\circ}-1180^{\circ} \mathrm{C}$. The near-solidus temperature indicated by the data of Green and others (1972), Ford and others (1972), and Walker and others (1972) is about $1100^{\circ} \mathrm{C}$, by which temperature nearly all the silicate melt had crystallized.

The experimental data on phase relations in the system Fe-Ni-P (Doan and Goldstein, 1970) suggest that the $\mathrm{Fe}-\mathrm{Ni}-\mathrm{P}-\mathrm{S}$ melt globules probably would not have been entirely solidified until temperatures $\leqslant 950^{\circ} \mathrm{C}$. Textures of silicate minerals surrounding the globules suggest that final solidification of mesostasis in the silicate melt took place at about the same temperature.

Textures of the Fe-Ni-P-S particles indicate that the magma was at no time quenched during its crystallization. In the particle shown in figure $9 A$, the bulk composition indicates that $\gamma \mathrm{Ni}-\mathrm{Fe}$ would have been the only phase crystallizing at temperatures above about $975^{\circ} \mathrm{C}$ (Doan and Goldstein, 1969, 1970 ), encompassing the range of crystallization of nearly all the surrounding silicate melt. The $\gamma \mathrm{Ni}-\mathrm{Fe}$ in this particle shows no evidence of any sudden temperature drop or abrupt loss of volatile $\mathrm{P}$ or $\mathrm{S}$ during its crystallization. It is smoothly zoned and grew slowly enough that it formed a single crystal.

Comparisons with experimental data on subsolidus phase relations in the $\mathrm{Fe}-\mathrm{Ni}-\mathrm{P}$ system (Doan and Goldstein, 1970) indicate that the Fe-Ni-P-S particles record the effects of equilibration to final temperatures betweer $800^{\circ}$ and $<550^{\circ} \mathrm{C}$. In the particle shown in figure $9 A$, an exsolved schreibersite lamella has a $\mathrm{Ni}$ content $\mathbf{1 . 7 5}$ percent lower than 
adjacent $\gamma \mathrm{Ni}-\mathrm{Fe}$, suggesting a final equilibration of the bulk lamella with surrounding metal at about $800^{\circ} \mathrm{C}$. In other similar particles, compositional differences between lamellae and host metal record temperatures as low as $650^{\circ} \mathrm{C}$. Comparisons of the average Ni contents of metal and of marginal schreibersite in individual composite particles yield equilibration temperatures for different bulk particles ranging from $800^{\circ}$ to $650^{\circ} \mathrm{C}$. For a particle of the bulk composition of the one in figure 9.4 , temperature of formation of $\alpha \mathrm{Ni}-\mathrm{Fe}$ should have been about $600^{\circ} \mathrm{C}$; the observed $\mathrm{Ni}$ contents of the $\alpha$ and $\gamma$ phases are consistent with this estimate. The lowest temperatures of equilibration are recorded at contacts between $\alpha \mathrm{Ni}-\mathrm{Fe}$ and schreibersite, where locally the latter mineral was highly enriched in $\mathrm{Ni}$. The most nickel-rich schreibersites analyzed contain 25.0 and 26.3 percent $\mathrm{Ni}$; $\mathrm{Ni}$ in adjacent $\alpha \mathrm{Ni}-\mathrm{Fe}$ is 8.7 and 7.4 percent, respectively. Equilibration temperatures indicated by the compositions of these two mineral pairs are less than $550^{\circ} \mathrm{C}$, possibly on the order of $500^{\circ} \mathrm{C}$. Axon and Goldstein (1972) estimated an even lower final equilibration temperature, about $450^{\circ} \mathrm{C}$, for one particle analyzed by El Goresy and others (1971) in their sample of 14310.

Data on subsolidus equilibration in pyroxenes indicate that final equilibration temperatures for these minerals were similar to those for metal and schreibersite. Studies of cation distribution in pyroxenes reported by Gibb and others (1972), Finger and others (1972) and Ghose and others (1972) yielded equilibration temperatures of about $625^{\circ}, 550^{\circ}$, and $700^{\circ} \mathrm{C}$, respectively.

Several authors have also discussed subsolidus cooling rates in 14310. Based on their studies of cation ordering in pyroxenes, Finger and others (1972) and Ghose and others (1972) found that the cooling rate was comparable to that of the coarsegrained Apollo 12 pigeonite basalt 12021. Ghose and others (1972), Lally and others (1972), and Takeda and Ridley (1972) variously stated that the rock cooled slowly relative to basalt 14053 , to Apollo 11 and 12 basalts, and to mare basalts in general. On the basis of their studies of particles of metal + schreibersite, Axon and Goldstein (1972) gave a quantitative estimate of cooling rate: from solidus to $700^{\circ} \mathrm{C}$ in 1 month.

\section{OXYGEN FUGACITY}

Oxygen fugacity in the 14310 melt throughout its crystallization appears to have been roughly comparable to that in the melts that crystallized to form the Apollo 12 basalts. Metal particles or metal-rich molten globules were present in both the 14310 and
Apollo 12 melts during the earliest parts of their crystallization sequences, and both types of basalt show similar reduction of ulvöspinel to ilmenite + $\mathrm{Fe}$ in the latest stages of crystallization. Comparisons of the observed natural mineral assemblages with experimental data permit some semiquantitative estimates of $f \mathrm{O}_{2}$ values at different points during crystallization. Experiments reported by Ford and others (1972) suggest that at the point of precipitation of the first mafic silicates, about $1200^{\circ} \mathrm{C}$, $\log f \mathrm{O}_{2}$ was between -11.6 and -14 and may have been closer to the latter value. Experimental data on $\log f_{\mathrm{O}_{2}}$ for the late-stage reduction of ulvöspinel (Taylor and others, 1972) indicate that when the silicate melt had cooled about to its solidus $\left(\sim 1000^{\circ} \mathrm{C}\right) \log \mathrm{fO}_{2}$ was probably less than -15.3 .

\section{VOLATILES}

The presence of volatiles in the melt and escape of volatiles during crystallization is attested to by the presence of vugs in the rock. Additional evidence for the escape of volatiles is the presence of reverse and oscillatory zoning in pyroxenes; such zoning is most likely the product of periodic degassing, for it is in some cases clearly associated with vugs. Crystals that grew near vugs are commonly coarser than elsewhere in the rock; therefore the volatiles that concentrated at these sites favored diffusion to existing crystal nuclei over nucleation of new grains, and possibly also favored relatively rapid grain growth. Composition of the volatile species is problematical. Wellman (1970) proposed that the major volatile species in Apollo 11 melts were $\mathrm{H}_{2}, \mathrm{H}_{2} \mathrm{O}, \mathrm{N}_{2}, \mathrm{CH}_{4}$, $\mathrm{CO}$, and $\mathrm{CO}_{2}$, and Motoaki Sato and R. T. Helz (oral commun., 1972) have suggested that $S_{2}, F_{2}$, and $\mathrm{Cl}_{2}$ might have been important volatiles in these and other lunar melts. In the 14310 melt it is possible that $P_{2}$ as well was a major volatile species.

\section{CONDITIONS OF CRYSTALLIZATION OF FINE-GRAINED CLOTS}

Conditions at the sites of crystallization of the fine-grained clots favored both formation of abundant nuclei of plagioclase and extensive growth of this mineral. Ridley and others (1972) have proposed that the clots may represent sites that differed from the rest of the melt in content of volatile species (from the data presented here, presumably different volatile species from those that formed vugs). There is some evidence that favors such an interpretation. Large composite particles of metal + schreibersite + troilite in and near clots commonly are enveloped by reaction rims of phosphate minerals 
(fig. $2 D$ ), suggesting possible higher $f \mathrm{O}_{2}$ at these sites than elsewhere in the melt. Analyses were made of the products and reactants involved in formation of one such reaction rim in an attempt to define the form of the reaction in order to be able to calculate its equilibrium $f \mathrm{O}_{2}$. The analyses, the derived reaction, and the calculated equilibrium $\mathrm{fO}_{2}$ values are presented below, but the results are not definitive. The calculated $\mathrm{fO}_{2}$ values are slightly higher than those estimated for the rock as a whole in the last stages of its crystallization, but the differences are well within the uncertainties in the calculation.

The area studied in detail is pictured in figure $2 D$. Textures indicate that the reactants were schreibersite (or phosphorus dissolved in metal) and pyroxene and products were whitlockite, silica glass, and probably also native $\mathrm{Fe}$. The whitlockite is fairly uniform in composition and contains $\mathrm{Ca}, \mathrm{Mg}$, and $\mathrm{Fe}$ in molar proportions 88:3:9; metal and schreibersite contain about 0.86 mole fraction Fe. Reacted pyroxene appears to be depleted in Ca relative to unreacted pyroxene, but $\mathrm{Ca}$ contents in both pyroxenes are quite variable (fig. 12). It appears that the reaction had the general form $3(\mathrm{Ca}, \mathrm{Mg}) \mathrm{SiO}_{3}+2 \mathrm{Fe}_{3} \mathrm{P}$ $+5 / 2 \mathrm{O}_{2}=(\mathrm{Ca}, \mathrm{Mg})_{3}\left(\mathrm{Po}_{4}\right)_{2}+3 \mathrm{SiO}_{2}+6 \mathrm{Fe}$. Oxygen fugacity at equilibrium at $1000^{\circ} \mathrm{C}$ was calculated for the related reaction: $3 \mathrm{CaSiO}_{3}+2 \mathrm{Fe}_{3} \mathrm{P}+5 / 2 \mathrm{O}_{2}$ $=\mathrm{Ca}_{3}\left(\mathrm{PO}_{4}\right)_{2}+3 \mathrm{SiO}_{2}+6 \mathrm{Fe}$. For this calculation, thermodynamic data were taken from Latimer (1952), Kelly (1960), Kelley and King (1961), and Kubaschewski and Evans (1958); activities were assumed to be equal to mole fractions. Because the pyroxenes show appreciable variability in Ca contents, two calculations were made, one with mole fraction of wollastonite set at 0.13 , the other at 0.19 . The values of $\log \mathrm{fO}_{2}$ derived from these two calculations are -14.7 and -14.9 , respectively. These values represent minimum values, because in the actual reaction the presence of $\mathrm{Ni}$ in the schreibersite and metal would have raised the equilibrium $\mathrm{fO}_{2}$ somewhat. Uncertainty in the thermodynamic data introduces considerable uncertainty into the results, however-on the order of at least \pm 0.5 . Moreover, if the reaction involved $\mathrm{P}$ dissolved in metal rather than $\mathrm{Fe}_{3} \mathrm{P}$, the $f_{2}$ could have differed by more than an order of magnitude from that calculated here (Olsen and Fuchs, 1967).

\section{GENESIS OF THE 14310 MAGMA}

From data presented here and by others, it appears that the large $\mathrm{Fe}-\mathrm{Ni}-\mathrm{P}-\mathrm{S}$ globules in basalt 14310 represent meteoritic contaminant material.
The very appearance of these particles suggests an exotic origin: Many are much larger than the rest of the metal-bearing grains, and they tend to occur in local concentrations. Their bulk compositions are appropriate for meteorite-derived particles (Axon and Goldstein, 1972), and the metal they contain has $\mathrm{Ni}-\mathrm{Co}-\mathrm{P}$ contents clearly distinct from the rest of the metal grains in the rock. Data on siderophile trace elements $\mathrm{Ir}, \mathrm{Re}$, and $\mathrm{Au}$-elements carried virtually entirely by the metal particles-provide further support for a meteoritic origin. Absolute abundances of these elements are unlike those in other lunar basalts, but are similar to those in lunar soil (Morgan and others, 1972). Moreover, ratios of $\mathrm{Re} / \mathrm{Au}$ and $\mathrm{Ir} / \mathrm{Au}$ in 14310 are close to those in lunar soils and in some classes of chondrites and appreciably different from those in mare basalts and other Apollo 14 basalts.

Thus it appears that the parent melt of 14310 began its crystallization at or near the lunar surface containing no more than 3-4 percent plagioclase crystals, perhaps none, and scattered globules of Fe-Ni-P-S immiscible melt (and possibly also crystalline metallic particles). The magma probably contained no silicate xenoliths or xenocrysts, and the metal-rich material was entirely melted or equilibrated with surrounding silicate melt prior to crystallization.

The presence of meteoritic contaminant suggests that the 14310 melt was generated at the lunar surface or in the upper levels of the lunar crust. Similarly, the results of experimental crystallization studies have indicated that derivation of the 14310 melt by partial melting deep within the moon is unlikely. These studies show that 14310 could not represent a direct anhydrous partial melt of likely lunar mantle material (Ford and others, 1972; Kushiro and others, 1972; Green and others, 1972; Walker and others, 1972). Kushiro (1972) and Ford and others (1972) suggested that if additional alkalis, or alkalis and water, were present in parent mantle during melting, a partial melt of $14310 \mathrm{com}$ position could have been generated. However, the presence of alkalis and (or) water during highpressure melting would have appreciably reduced the liquidus temperature of the melt, and it should have begun to crystallize on the lunar surface at a temperature below that of its anhydrous liquidus; this was not the case. Hypotheses that invoke crystal accumulation into a mantle-generated melt to explain the high plagioclase content of the rock are not admissible because the texture indicates that no such accumulation has occurred. Moreover, it is improbable that 14310 represents a mantle-generated melt 
that incorporated feldspathic and meteoritic debris from the regolith upon extrusion, because it would have been necessary for such a melt to possess an unreasonable degree of superheat in order to retain a temperature $>1310^{\circ} \mathrm{C}$ after melting all incorporated material.

From the above lines of evidence it appears that there are two possible ways in which the 14310 melt could have been generated: (1) by partial or bulk melting of a feldspathic rock in the lunar crust (Kushiro, 1972; Walker and others, 1972) ; or (2) by impact melting of feldspar-rich lunar surface materials (Dence and others, 1972; Axon and Goldstein, 1972; Ehmann and others, 1972; Green and others, 1972; Schnetzler and others, 1972; Hollister and others, 1972). In either case, the parental material must have been feldspar rich and probably was derived from rocks of a preexisting feldspathic lunar crust.

In the first hypothesis, that of partial melting in the lunar crust, the parent material necessarily would have contained meteoritic metal and might most likely have been consolidated or unconsolidated impact debris. This hypothesis, however, requires that very high temperatures be generated by processes other than direct shock melting very near the lunar surface-temperatures of at least $1310^{\circ} \mathrm{C}$ and possibly considerably higher if the apparent liquidus temperatures of the $\mathrm{Fe}-\mathrm{Ni}-\mathrm{P}-\mathrm{S}$ melt globules represent their true liquidus temperatures. Such high temperatures of partial melting so close to the lunar surface would not be expected on the basis of terrestrial experience, but the evidence that some lunar breccias have been recrystallized at temperatures on the order of $1000^{\circ}-1100^{\circ} \mathrm{C}$ (Williams, 1972 ; Grieve and others, 1972; Anderson and others, 1972) indicates that it might have been possible for even higher temperatures to be generated locally in nearsurface rocks.

In the second hypothesis, that of impact melting, the problem of finding a plausible heat source is removed. Generation of melts that have very high temperatures indeed is possible by shock. For this reason I favor the interpretation that impact melting in some form was important in generation of the 14310 melt; however, the possible schemes of genesis involving impact are numerous, and a probable parent material is not easily specified. For example, the 14310 melt could represent: an impact melt of lunar rock, with addition only of $\mathrm{Fe}-\mathrm{Ni}-\mathrm{P}-\mathrm{S}$ particles from the impacting body; an impact melt of regolith or microbreccia; a contaminated melt consisting of a mixture of impact melt with impact debris; or a hybrid melt consisting of a mixture of impact melt with magma derived from the lunar interior.

If indeed basalt 14310 crystallized from an impact melt, its crystallization history demonstrates that on the surface of the moon in its early history impact melts were formed that were not rapidly quenched. They instead followed crystallization paths like those of mare basalts, or were incorporated into melts that followed such paths. Distinction of such melts from magmas formed in the lunar interior adds yet another dimension of complexity to studies of lunar petrology, but such distinction is necessary before questions of the genesis, evolution, and thermal history of the lunar mantle and crust can be considered in the light of petrologic evidence.

\section{REFERENCES CITED}

Anderson, A. T., Jr., Braziunas, T. F., Jacoby, J., and Smith, J. V., 1972, Thermal and mechanical history of breccias 14306, 14063, 14270, and 14321, in Proceedings of the Third Lunar Science Conference, v. 1: Cambridge, Mass., MIT Press, p. 819-835 (Geochim. et Cosmochim. Acta Supp. 3, v. 1).

Axon, H. J., and Goldstein, J. I., 1972, Temperature-time relationships from lunar two phase metallic particles $(14310,14163,14003)$ : Earth and Planetary Sci. Letters, v. 16, p. 439-447.

Bence, A. E., and Papike, J. J., 1972, Pyroxenes as recorders of lunar basalt petrogenesis; Chemical trends due to crystal liquid interaction, in Proceedings of the Third Lunar Science Conference, v. 1: Cambridge, Mass., MIT Press, p. 431-469 (Geochim. et Cosmochim. Acta Supp. $3, \mathrm{v} .1)$.

Boyd, F. R., Finger, L. W., and Chayes, F., 1969, Computer reduction of electron-probe data: Carnegie Inst. Washington Year Book 67, 1967-68, p. 210-215.

Boyd, F. R., and Smith, Douglas, 1971, Compositional zoning in pyroxenes from lunar rock 12021, Oceanus Procellarum: Jour. Petrology, v. 12, p. 439-464.

Brown, G. M., and Peckett, A., 1971, Selective volatilization on the lunar surface; Evidence from Apollo 14 feldsparphyric basalts: Nature, v. 234, p. 262-266.

Brown, G. M., Emeleus, C. H., Holland, J. G., Peckett, A., and Phillips, R., 1972, Mineral-chemical variations in Apollo 14 and Apollo 15 basalts and granitic fractions, in Proceedings of the Third Lunar Science Conference, v. 1: Cambridge, Mass., MIT Press, p. 141-157 (Geochim. et Cosmochim. Acta Supp. 3, v. 1).

Compston, W., Vernon, M. J., Berry, H., Rudowski, R., Gray, C. M., Ware, N., Chappell, B. W., and Kaye, M., 1972a, Age and petrogenesis of Apollo 14 basalts [abs.], in Lunar Science, III: Lunar Sci. Inst. Contr. 88, p. 151-153.

Compston, W., Vernon, M. J., Berry, H., Rudowski, R., Gray, C. M., and Ware, N., 1972b, Apollo 14 mineral ages and the thermal history of the Fra Mauro formation, in Proceedings of the Third Lunar Science Conference, v. 2: Cambridge, Mass., MIT Press, p. 1487-1501 (Geochim. et Cosmochim. Acta Supp. 3, v. 2). 
Dence, M. R., and Plant, A. G., 1972, Analysis of Fra Mauro samples and origin of the Imbrian basin, in Proceedings of the Third Lunar Science Conference, v. 1: Cambridge, Mass., MIT Press, p. 379-399 (Geochim. et Cosmochim. Acta Supp. 3, v. 1).

Dence, M. R., Plant, A. G., and Traill, R. J., 1972, Impactgenerated shock and thermal metamorphism in Fra Mauro lunar samples [abs.], in Lunar Science, III: Lunar Sci. Inst. Contr. 88, p. 174-176.

Doan, A. S., Jr., and Goldstein, J. I., 1969, The formation of phosphides in iron meteorites, in Millman, P. M., ed., Meteorite Research: New York, Springer-Verlag, p. 763779 .

- 1970, The ternary phase diagram, Fe-Ni-P: Metall. Trans., v. 1, p. 1759-1767.

Drever, H. I., Johnston, R., Butler, P., Jr., Gibb, F. G. F., and Whitley, J. E., 1972, Some textures in lunar igneous rocks and terrestrial analogs [abs.], in Lunar Science, III: Lunar Sci. Inst. Contr. 88, p. 189-191.

Ehmann, W. D., Gillum, D. E., and Morgan, J. W., 1972, Oxygen and bulk element composition studies of Apollo 14 and other lunar rocks and soils, in Proceedings of the Third Lunar Science Conference, v. 2: Cambridge, Mass., MIT Press, p. 1149-1160 (Geochim. et Cosmochim. Acta Supp. 3, v. 2).

El Goresy, Ahmed, Ramdohr, Paul, and Taylor, L. A., 1971, The geochemistry of the opaque minerals in Apollo 14 crystalline rocks: Earth and Planetary Sci. Letters, v. 13 , no. 1 , p. $121-129$.

El Goresy, Ahmed, Taylor, L. A., and Ramdohr, Paul, 1972, Fra Mauro crystalline rocks: Mineralogy, geochemistry, and subsolidus reduction of the opaque minerals, in Proceedings of the Third Lunar Science Conference, v. 1: Cambridge, Mass., MIT Press, p. 333-349 (Geochim. et Cosmochim. Acta Supp. 3, v. 1).

Finger, L. W., Hafner, S. S., Schürmann, K., Virgo, D., and Warburton, D., 1972, Distinct cooling histories and reheating of Apollo 14 rocks [abs.], in Lunar Science, III : Lunar Sci. Inst. Contr. 88, p. 259-261.

Ford, C. E., Biggar, G. M., Humphries, D. J., Wilson, G., Dixon, D., and O'Hara, M. J., 1972, Role of water in the evolution of the Iunar crust; an experimental study of sample 14310; an indication of lunar calc-alkaline volcanism, in Proceedings of the Third Lunar Science Conference, v. 1: Cambridge, Mass., MIT Press, p. 207229 (Geochim. et Cosmochim. Acta Supp. 3, v. 1).

Gancarz, A. J., Albee, A. L. and Chodos, A. A., 1971, Petrologic and mineralogic investigation of some crystalline rocks returned by the Apollo 14 mission: Earth and Planetary Sci. Letters, v. 12, no. 1, p. 1-18.

Ghose, Subrata, Ng, George, and Walter, L. S., 1972, Clinopyroxenes from Apollo 12 and 14: Exsolution, domain structure, and cation order, in Proceedings of the Third Lunar Science Conference, v. 1: Cambridge, Mass., MIT Press, p. 507-531 (Geochim. et Cosmochim. Acta Supp. 3, v. 1).

Gibb, T. C., Greatrex, R., Greenwood, N. N., and Battey, M. H., 1972, Mössbauer studies of Apollo 14 lunar samples, in Proceedings of the Third Lunar Science Conference, v. 3: Cambridge, Mass., MIT Press, p. 24792493 (Geochim. et Cosmochim. Acta Supp. 3, v. 3).

Green, D. H., Ringwood, A. E., Ware, N. G., and Hibberson, W. O., 1972, Experimental petrology and petro- genesis of Apollo 14 basalts, in Proceedings of the Third Lunar Science Conference, v. 1: Cambridge, Mass., MIT Press, p. 197-206 (Geochim. et Cosmochim. Acta Supp. 3, v. 1).

Grieve, R., McKay, G., Smith, H., Weill, D., and McCallum, S., 1972, Mineralogy and petrology of polymict breccia 14321 [abs.], in Lunar Science, III: Lunar Sci. Inst. Contr. 88, p. 338-340.

Griffin, W. L., Amli, R., and Heier, K. S., 1972, Whitlockite and apatite from lunar rock 14310 and from Oedegarden, Norway: Earth and Planetary Sci. Letters, v. 15, p. 53-58.

Haggerty, S. E., 1972, Apollo 14: Subsolidus reduction and compositional variations of spinels, in Proceedings of the Third Lunar Science Conference, v. 1: Cambridge, Mass., MIT Press, p. 305-332 (Geochim. et Cosmochim. Acta Supp. 3, v. 1).

Hansen, Max, and Anderko, Kurt, 1958, Constitution of binary alloys: 2d ed., New York, McGraw-Hill, 1305 p.

Hollister, L. S., 1972, Implications of the relative concentrations of $\mathrm{Al}, \mathrm{Ti}$, and $\mathrm{Cr}$ in lunar pyroxenes [abs.], in Lunar Science, III: Lunar Sci. Inst. Contr. 88, p. 389391.

Hollister, L., Trzcienski, W., Jr., Dymek, R., Kulick, C., Weigand, P., and Hargraves, R., 1972, Igneous fragment 14310,21 and the origin of the mare basalts [abs.], in Lunar Science, III : Lunar Sci. Inst. Contr. 88, p. $386-388$.

Hubbard, N. J., Gast, P. W., Rhodes, J. M., Bansal, B. M., Wiesmann, H., and Church, S. E., 1972, Nonmare basalts: Part II, in Proceedings of the Third Lunar Science Conference, v. 2: Cambridge, Mass., MIT Press, p. 1161-1179 (Geochim. et Cosmochim. Acta Supp. 3, v. 2).

Huebner, J. S., and Ross, Malcolm, 1972, Phase relations of lunar and terrestrial pyroxenes at one atm. [abs.], in Lunar Science, III: Lunar Sci. Inst. Contr. 88, p. 410 412.

Kelley, K. K., 1960, Contributions to the data on theoretical metallurgy. 13. High temperature heat-content, heatcapacity, and entropy data for the elements and inorganic compounds: U.S. Bur. of Mines Bull. 584, 232 p.

Kelley, K. K., and King, E. G., 1961, Contributions to the data on theoretical metallurgy. 14. Entropies of the elements and inorganic compounds: U.S. Bur. Mines Bull. 592, 149 p.

Kubaschewski, Oswald, and Evans, E. LL., 1958, Metallurgical Thermochemistry: 2d rev. ed., New York, Pergamon Press, 426 p.

Kushiro, Ikuo, 1972, Petrology of lunar high-alumina basalt [abs.], in Lunar Science, III: Lunar Sci. Inst. Contr. 88, p. $466-468$.

Kushiro, Ikuo, Ikeda, Yukio, and Nakamura, Yasuoa, 1972, Petrology of Apollo 14 high-alumina basalt, in Proceedings of the Third Lunar Science Conference, v. 1: Cambridge, Mass., MIT Press, p. 115-129 (Geochim. et Cosmochim. Acta Supp. 3, v. 1).

Lally, J. S.. Fisher, R. M., Christie, J. M., Griggs, D. T., Heuer, A. H., Nord, G. L., Jr., and Radcliffe, S. V., 1972, Electron petrography of Apollo 14 and 15 rocks, in Proceedings of the Third Lunar Science Conference, v. 1: Cambridge, Mass., MIT Press, p. 401-422 (Geochim. et Cosmochim. Acta Supp. 3, v. 1). 
Latimer, W. M., 1952, The oxidation states of the elements and their potentials in aqueous solutions: New York, Prentice-Hall, Inc., 392 p.

Longhi, John, Walker, David, and Hays, J. F., 1972, Petrography and crystallization history of basalts 14310 and 14072, in Proceedings of the Third Lunar Science Conference, v. 1: Cambridge, Mass., MIT Press, p. 131139 (Geochim. et Cosmochim. Acta Supp. 3, v. 1).

LSPET (Lunar Sample Preliminary Examination Team), 1971, Preliminary examination of lunar samples from Apollo 14: Science, v. 173, p. 681-693.

Melson, W. G., Mason, B., Nelen, J., and Jacobson, S., 1972, Apollo 14 basaltic rocks [abs.], in Lunar Science, III: Lunar Sci. Inst. Contr. 88, p. 535-536.

Morgan, J .W., Laul, J. C., Krähenbühl, Urs, Ganapathy, R., and Anders, Edward, 1972, Major impacts on the moon: Characterization from trace elements in Apollo 12 and 14 samples, in Proceedings of the Third Lunar Science Conference, v. 2: Cambridge, Mass., MIT Press, p. 13771396 (Geochim. et Cosmochim. Acta Supp. 3, v. 2).

Murthy, V. R., Evensen, N. M., Jahn, Bor-ming, and Coscio, M. R., Jr., 1972, Apollo 14 and 15 samples: Rb-Sr ages, trace elements, and lunar evolution, in Proceedings of the Third Lunar Science Conference, v. 2: Cambridge, Mass., MIT Press, p. 1503-1514 (Geochim. et Cosmochim. Acta Supp. 3, v. 2).

Olsen, E., and Fuchs, L. H., 1967, The state of oxidation of some iron meteorites: Icarus, v. 6, p. 242-253.

Papanastassiou, D. A., and Wasserburg, G. J., 1971, Rb-Sr ages of igneous rocks from the Apollo 14 mission and the age of the Fra Mauro formation: Earth and Planetary Sci. Letters, v. 12 , no. 1, p. 36-48.

Philpotts, J. A., Schnetzler, C. C., Nava, D. F., Bottino, M. L., Fullagar, P. D., Thomas, H. H., Schuhmann, Shuford, and Kouns, C. W., 1972, Apollo 14: Some geochemical aspects, in Proceedings of the Third Lunar Science Conference, v. 2: Cambridge, Mass., MIT Press, p. 1293-1305 (Geochim. et Cosmochim. Acta Supp. 3, v. 2).

Ridley, W. I., Brett, Robin, Williams, R. J., Takeda, Hiroshi, and Brown, R. W., 1972, Petrology of Fra Mauro Basalt 14310 , in Proceedings of the Third Lunar Science Conference, v. 1: Cambridge, Mass., MIT Press, p. 159-170 (Geochim. et Cosmochim. Acta Supp. 3, v. 2).

Ringwood, A. E., Green, D. H., and Ware, N. G., 1972, Experimental petrology and petrogenesis of Apollo 14 basalts [abs.], in Lunar Science, III: Lunar Sci. Inst. Contr. 88, p. 654-656.

Roedder, Edwin, and Weiblen, P. W., 1972, Petrographic features and petrologic significance of melt inclusions in Apollo 14 and 15 rocks, in Proceedings of the Third Lunar Science Conference, v. 1: Cambridge, Mass., MIT Press, p. 251-279 (Geochim. et Cosmochim. Acta Supp. 3, v. 1).

Rose, H. J., Jr., Cuttitta, Frank, Annell, C. S., Carron, M. K., Christian, R. P., Dwornik, E. J., Greenland, L. P., and Ligon, D. T., Jr., 1972, Compositional data for twenty-one Fra Mauro lunar materials, in Proceedings of the Third Lunar Science Conference, v. 2: Cambridge, Mass., MIT Press, p. 1215-1229 (Geochim. et Cosmochim. Acta Supp. 3, v. 2).

Ross, M., Huebner, J. S., and Dowty, E., 1973, Delineation of the one atmosphere augite-pigeonite miscibility gap for pyroxenes from lunar basalt 12021: Am. Mineralogist, v. 58. (In press.)

Schnetzler, C. C., Philpotts, J. A., Nava, D. F., Thomas, H. H., Bottino, M. L. and Barker, J. L., Jr., 1972, Chemical compositions of Apollo 14, Apollo 15, and Luna 16 materials [abs.], in Lunar Science, III: Lunar Sci. Inst. Cont. 88, p. 682 .

Schürmann, K., and Hafner, S. S., 1972, Distinct subsolidus cooling histories of Apollo 14 basalts, in Proceedings of the Third Lunar Science Conference, v. 1: Cambridge, Mass., MIT Press, p. 493-506 (Geochim. et Cosmochim. Acta Supp. 3, v. 1).

Skinner, B. J., 1970, High crystallization temperatures indicated for igneous rocks from Tranquillity Base, in Proceedings of the Apollo 11 Lunar Science Conference, v. 1: New York, Pergamon Press, p. 891-895 (Geochim. et Cosmochim. Acta Supp. 1, v. 1).

Swann, G. A., Trask, N. J., Hait, M. H., and Sutton, R. L., 1971, Geologic setting of the Apollo 14 samples: Science, v. 173 , p. $716-719$.

Takeda, Hiroshi, and Ridley, W. I., 1972, Crystallography and chemical trends of orthopyroxene-pigeonite from rock 14310 and coarse fine 12033, in Proceedings of the Third Lunar Science Conference, v. 1: Cambridge, Mass., MIT Press, p. 423-430 (Geochim. et Cosmochim. Acta Suppl. 3, v. 1).

Taylor, L. A., Williams, R. J., and McCallister, R. H., 1972, Stability relations of ilmenite and ulvöspinel in the Fe-Ti-O system and application of these data to lunar mineral assemblages: Earth and Planetary Sci. Letters, v. 16, p. $282-288$.

Trzcienski, W. E., Jr., and Kulick, C. G., 1972, Plagioclase and $\mathrm{Ba}-\mathrm{K}$ phases from Apollo samples 12063 and 14310, in Proceedings of the Third Lunar Science Conference, v. 1: Cambridge, Mass., MIT Press, p. 519-602 (Geochim. et Cosmochim. Acta Supp. 3, v. 1).

Turner, G., Huneke, J. C., Podosek, F. A., and Wasserburg, G. J., $1971,{ }^{40} \mathrm{Ar}-{ }^{39} \mathrm{Ar}$ ages and cosmic ray exposure ages of Apollo 14 samples: Earth and Planetary Sci. Letters, v. 12, p. 19-35.

Walker, David, Longhi, John, and Hays, J. F., 1972, Experimental petrology and origin of Fra Mauro rocks and soil, in Proceedings of the Third Lunar Science Conference, v. 1: Cambridge, Mass., MIT Press, p. 797-817 (Geochim. et Cosmochim. Acta Supp. 3, v. 1).

Walter, L. S., French, B. M., Doan, A. S., Jr., and Henrich, K. F. J., 1972, Petrographic analysis of lunar samples 14171 and 14305 (breccias) and 14310 (melt rock) [abs.], in Lunar Science, III; Lunar Sci. Inst. Contr. 88 , p. $773-775$.

Wellman, T. R., 1970, Gaseous species in equilibrium with the Apollo 11 holocrystalline rocks during their crystallization: Nature, v. 225, p. 716-717.

Williams, R. J., 1972, The lithification and metamorphism of lunar breccias: Earth and Planetary Sci. Letters, v. 16, p. $250-256$.

Willis, J. P., Erlank, A. J., Gurney, J. J., Theil, R. H., and and Ahrens, L. H., 1972, Major, minor, and trace element data for some Apollo 11, 12, 14, and 15 samples, in Proceedings of the Third Lunar Science Conference, v. 2: Cambridge, Mass., MIT Press, p. 1269-1273 (Geochim. et Cosmochim. Acta Supp. 3, v. 2).

Wright, T. L., and Doherty, P. C., 1970, A linear program- 
ming and least squares computer method for solving petrologic mixing problems: Geol. Soc. America Bull., v. 81 , p. 1995-2008.

York, Derek, Kenyon, W. J., and Doyle, R. J., 1972, ${ }^{40} \mathrm{Ar}-{ }^{39} \mathrm{Ar}$ ages of Apollo 14 and 15 samples, in Proceedings of the Third Lunar Science Conference, v. 2: Cambridge, Mass., MIT Press, p. 1613-1622 (Geochim. et Cosmochim. Acta Supp. 3, v. 2).

H U.S. GOVERNMENT PRINTING OFFICE: 1973-515-659/67 


